\title{
National Assessment of Geologic Carbon Dioxide Storage Resources-Methodology Implementation
}

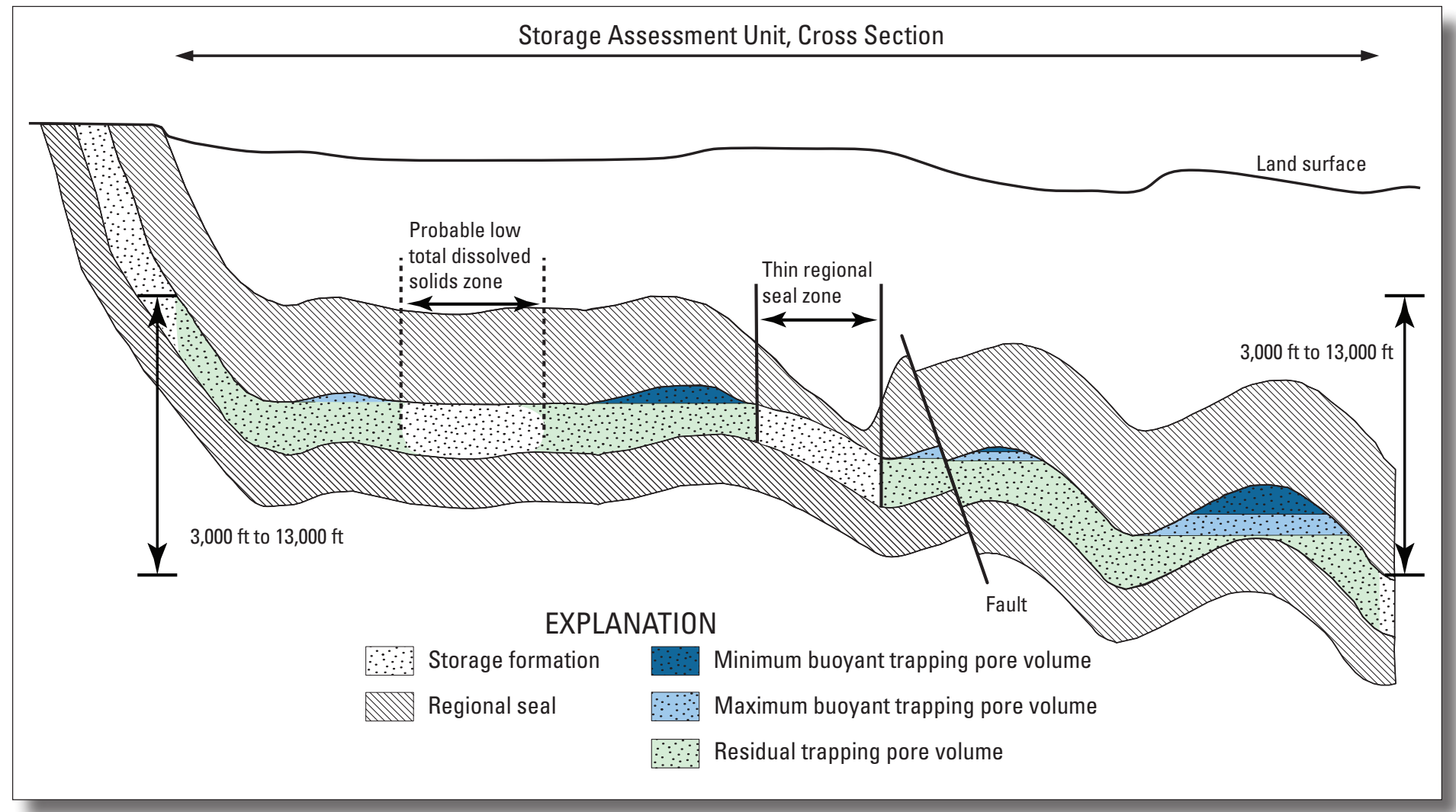

Open-File Report 2013-1055 


\section{National Assessment of Geologic Carbon Dioxide Storage Resources-Methodology Implementation}

By Madalyn S. Blondes, Sean T. Brennan, Matthew D. Merrill, Marc L. Buursink, Peter D. Warwick, Steven M. Cahan, Troy A. Cook, Margo D. Corum, William H. Craddock, Christina A. DeVera, Ronald M. Drake II, Lawrence J. Drew, Philip A. Freeman, Celeste D. Lohr, Ricardo A. Olea, Tina L. Roberts-Ashby, Ernie R. Slucher, and Brian A. Varela

Open-File Report 2013-1055 


\title{
U.S. Department of the Interior SALLY JEWELL, Secretary
}

\section{U.S. Geological Survey Suzette M. Kimball, Acting Director}

\author{
U.S. Geological Survey, Reston, Virginia: 2013
}

For more information on the USGS - the Federal source for science about the Earth, its natural and living resources, natural hazards, and the environment, visit http://www.usgs.gov or call 1-888-ASK-USGS.

For an overview of USGS information products, including maps, imagery, and publications, visit http://www.usgs.gov/pubprod

To order this and other USGS information products, visit http://store.usgs.gov

Any use of trade, firm, or product names is for descriptive purposes only and does not imply endorsement by the U.S. Government.

Although this information product, for the most part, is in the public domain, it also may contain copyrighted materials as noted in the text. Permission to reproduce copyrighted items must be secured from the copyright owner.

Suggested citation:

Blondes, M.S., Brennan, S.T., Merrill, M.D., Buursink, M.L., Warwick, P.D., Cahan, S.M., Cook, T.A., Corum, M.D., Craddock, W.H., DeVera, C.A, Drake, R.M., II, Drew, L.J., Freeman, P.A., Lohr, C.D., Olea, R.A., Roberts-Ashby, T.L., Slucher, E.R., and Varela, B.A., 2013, National assessment of geologic carbon dioxide storage resourcesMethodology implementation: U.S. Geological Survey Open-File Report 2013-1055, 26 p., http://pubs.usgs.gov/ of/2013/1055/. 


\section{Contents}

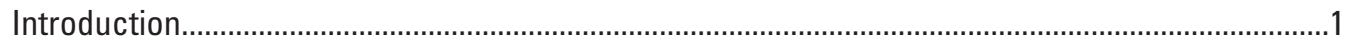

1. Criteria for Choosing and Classifying Storage Assessment Units...............................................

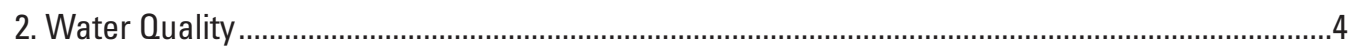

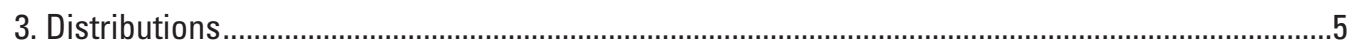

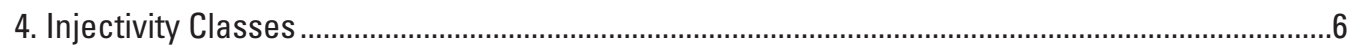

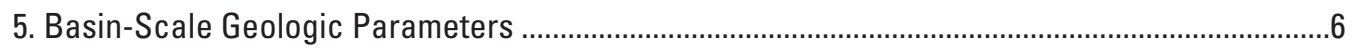

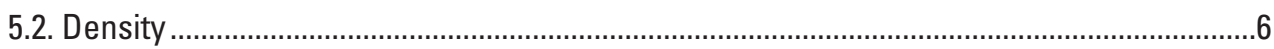

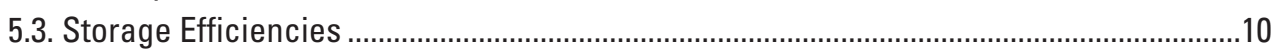

5.3.1. Residual Trapping Storage Efficiencies ...............................................................10

5.3.2. Buoyant Trapping Storage Efficiencies..................................................................12

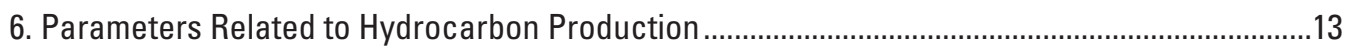

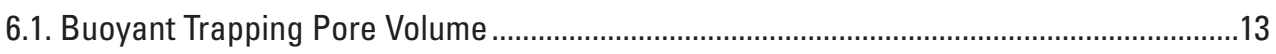

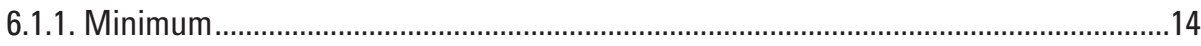

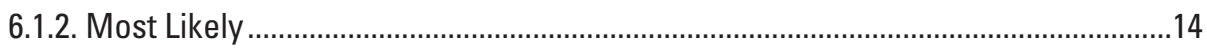

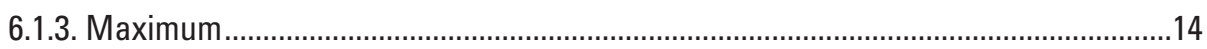

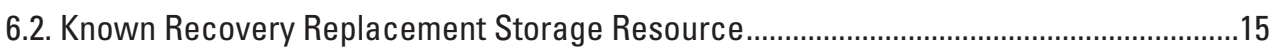

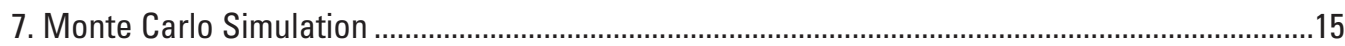

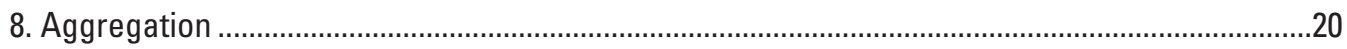

9. Summary

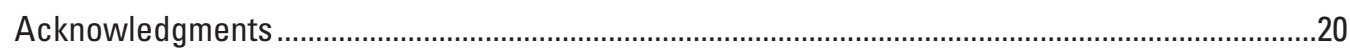

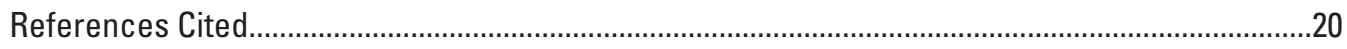

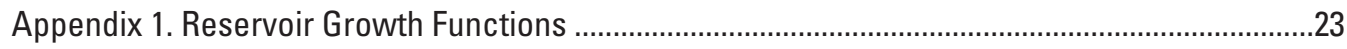

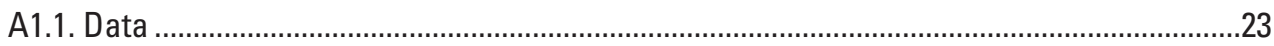

A1.2. Calibration of cumulative growth functions ..........................................................2

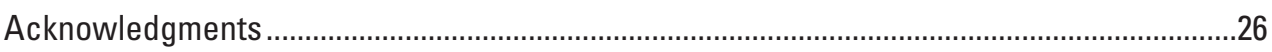

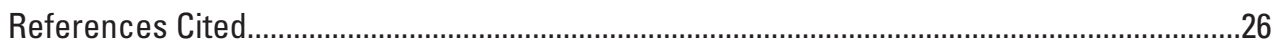




\section{Figures}

1. U.S. Geological Survey carbon dioxide $\left(\mathrm{CO}_{2}\right)$ sequestration assessment input data form

2. Schematic cross section through a storage assessment unit (SAU) illustrating the relation between buoyant and residual trapping styles in the storage formation.............4

3. Residual trapping injectivity class fractions ................................................................

4. Formation volume factors versus depth for the Uinta and Piceance Basins ....................8

5. Carbon dioxide $\left(\mathrm{CO}_{2}\right)$ density versus depth for the Uinta and Piceance Basins ................9

6. Carbon dioxide $\left(\mathrm{CO}_{2}\right)$ density versus depth for the Appalachian Basin ...........................11

7. Residual trapping storage efficiency (class 1 and class 2 ) versus depth for the Uinta and Piceance Basins

8. Example buoyant trapping storage probability density plots used to estimate minimum (MIN) and most likely (M. LIKELY) buoyant trapping storage volume inputs

9. Monte Carlo model calculations

10. Flow diagram of the key steps for calculating known recovery replacement storage resources $\left(K R R_{S R}\right)$, buoyant trapping storage resources $\left(B_{S R}\right)$, residual trapping storage resources $\left(R 1_{S R^{\prime}} R 2_{S R^{\prime}} R 3_{S R}\right)$, and technically accessible storage resources $\left(T A_{S R}\right)$. 


\section{Conversion Factors}

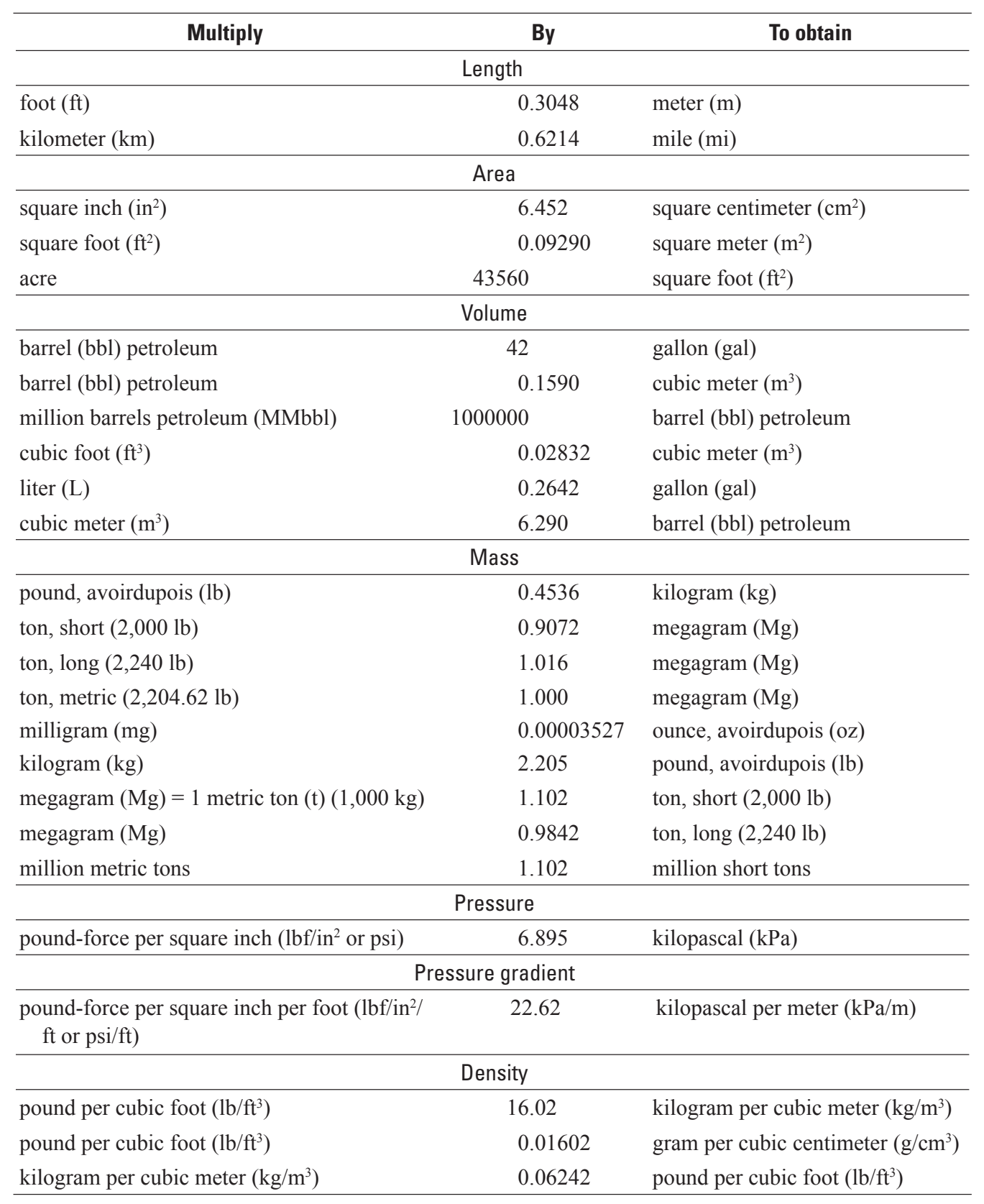




\section{Abbreviations, Acronyms, and Symbols}

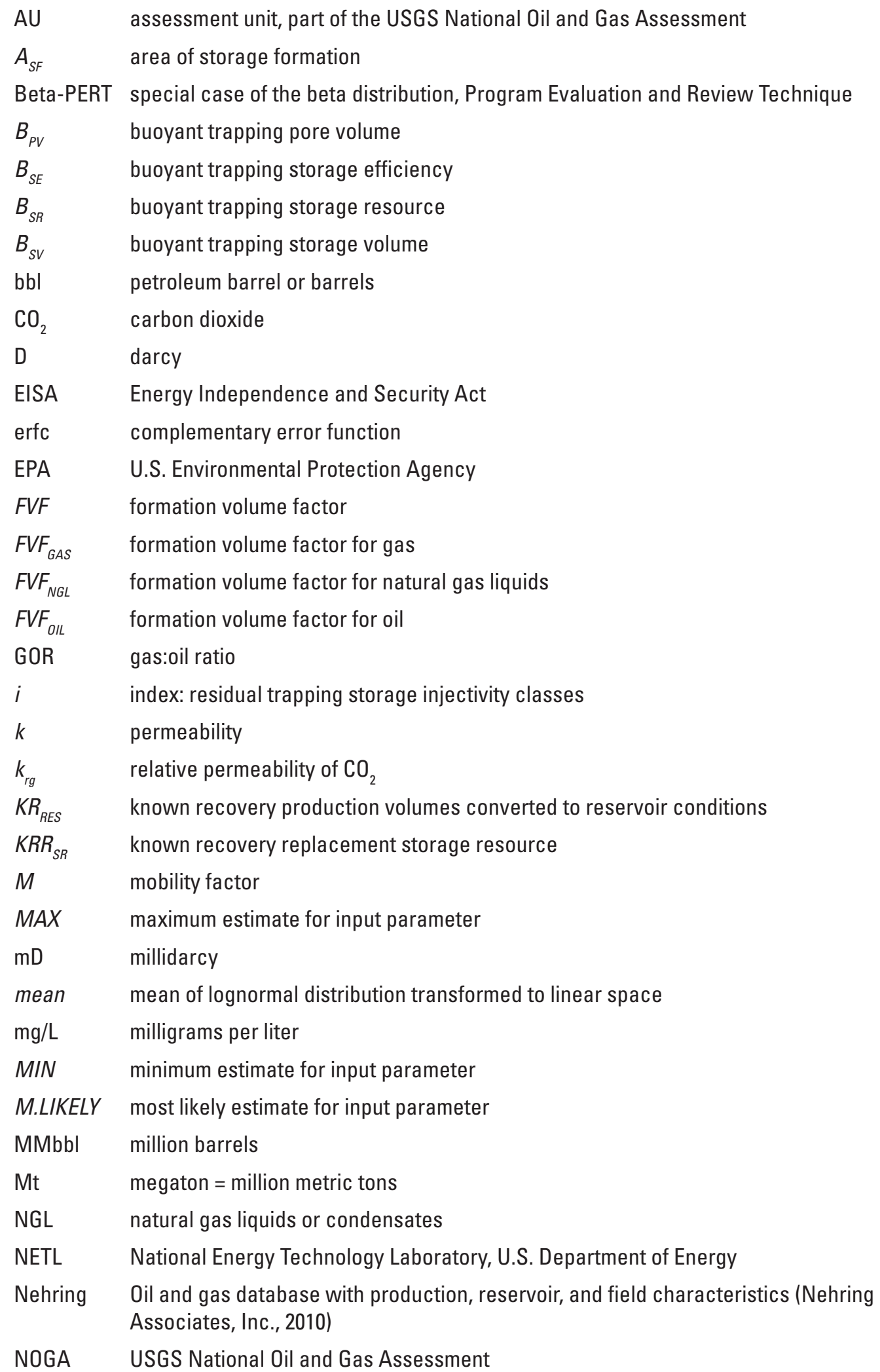




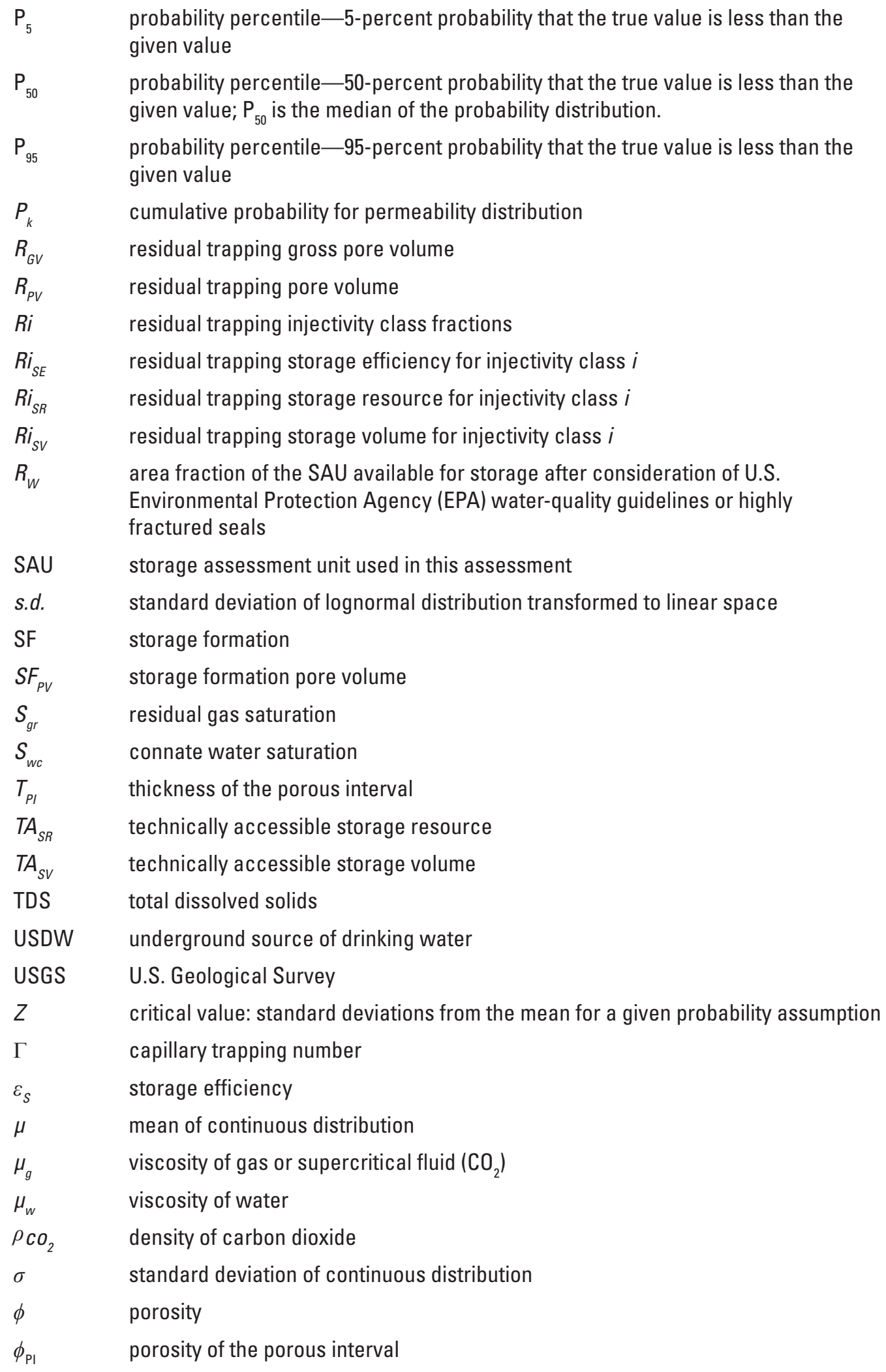




\title{
National Assessment of Geologic Carbon Dioxide Storage Resources-Methodology Implementation
}

\author{
By Madalyn S. Blondes, Sean T. Brennan, Matthew D. Merrill, Marc L. Buursink, Peter D. Warwick, \\ Steven M. Cahan, Troy A. Cook, Margo D. Corum, William H. Craddock, Christina A. DeVera, \\ Ronald M. Drake II, Lawrence J. Drew, Philip A. Freeman, Celeste D. Lohr, Ricardo A. Olea, \\ Tina L. Roberts-Ashby, Ernie R. Slucher, and Brian A. Varela
}

\section{Introduction}

In response to the Energy Independence and Security Act (Public Law 110-40, 2007), the U.S. Geological Survey (USGS) conducted a national assessment of potential geologic storage resources for carbon dioxide $\left(\mathrm{CO}_{2}\right)$. Storage of $\mathrm{CO}_{2}$ in subsurface saline formations is one important method to reduce greenhouse gas emissions and curb global climate change (Benson and Cook, 2005). The assessment methodology (Brennan and others, 2010; Burruss and others, 2009) describes the probabilistic model developed to calculate potential storage resources in subsurface saline formations. This report documents both the methodology updates and the details of methodology implementation and is meant to supplement the Brennan and others (2010) methodology and the national assessment final reports. The final reports will include (1) an assessment results report with all output results, a description of the assessment, and analysis (U.S. Geological Survey Geologic Carbon Dioxide Storage Resources Assessment Team, in press, a); (2) an assessment summary report (U.S. Geological Survey Geologic Carbon Dioxide Storage Resources Assessment Team, in press, b); and (3) an assessment data report, which will include data inputs and outputs, assessment forms (fig. 1), resource allocations, and figures.

The assessment has six output categories for each storage assessment unit (SAU). The first is the known recovery replacement storage resource $\left(K R R_{\mathrm{SR}}\right)$, which is the storage resource calculated from known production volumes. The second is the buoyant trapping storage resource $\left(B_{S R}\right)$, where $\mathrm{CO}_{2}$ may be trapped buoyantly beneath stratigraphic or structural geologic traps. Residual trapping storage resources comprise the next three categories $\left(R 1_{S R}, R 2_{S R}\right.$, and $\left.R 3_{S R}\right)$ and are in reservoirs where $\mathrm{CO}_{2}$ is trapped in pore spaces by capillary forces after plume migration. The residual trapping reservoirs are apportioned into three injectivity classes by rock permeability characteristics, each with an associated residual trapping storage efficiency. The final category is the technically accessible storage resource $\left(T A_{S R}\right)$, which is the sum of the buoyant and residual trapping storage resources. Over the course of the two-year assessment phase of the project, implementation adjustments to the methodology were necessary to generate the most accurate storage resource estimates.

All of the outputs, excluding the $K R R_{S R}$, can be summarized from the Brennan and others (2010) methodology with equation 1

$$
\begin{gathered}
T A_{S R}=\rho_{C O_{2}} B_{P V} B_{S E}+ \\
\sum_{i=1}^{3}\left[\rho_{C O_{2}}\left(A_{S F} T_{P I} \phi_{P I}-B_{P V}\right) R_{W} R i_{S E} R i\right]
\end{gathered}
$$

The buoyant trapping storage resource, $B_{S R}$, is equivalent to the first term on the right-hand side of the equation $\left(B_{S R}=\rho_{C O_{2}} B_{P V} B_{S E}\right)$. Each of the three terms in the summation is a residual trapping storage-resource output, $R 1_{S R}, R 2_{S R}$, or $R 3_{S R}$.

- $\rho_{\mathrm{CO}_{2}}$ is the density of $\mathrm{CO}_{2}$ and is determined from subsurface geothermal and pressure gradient data for each basin, by using analog basins, or from published gradients (see Section 6 of this report).

- $B_{P V}$ is the geologically determined pore volume that can store $\mathrm{CO}_{2}$ by buoyant trapping. It is estimated based on hydrocarbon production, undiscovered resources, and volume calculations of geologic traps (see Section 5).

- $B_{S E}$ and $R i_{S E}$ are the buoyant and residual trapping storage efficiencies, respectively, defined as the fraction of accessible pore volume that will be occupied by injected $\mathrm{CO}_{2}$. These are determined from estimates of subsurface geothermal and pressure gradients, multiphase flow parameters, and fluid chemistry and have values between 0 and 1 (see Section 4).

- $A_{S F}$ is the area of the SAU and is constrained using structure maps or data at the relevant depth ranges for the storage formation (SF). Methods used to estimate area are thoroughly described in Brennan and others (2010) and are not further addressed here. 
- $T_{P I}$ is the thickness of the net porous interval and is generally calculated using net-to-gross thickness assumptions applied to the total SAU thickness. Methods used to estimate thickness are thoroughly described in Brennan and others (2010) and are not further addressed here.

- $\phi_{P I}$ is the porosity of the net porous interval, which is obtained from available or analog rock porosity data. Methods used to estimate porosity are thoroughly described in Brennan and others (2010) and are not further addressed here.

- $R_{W}$ is the area fraction of the SAU available for storage after consideration of U.S. Environmental Protection Agency (EPA) water-quality guidelines or highly fractured seals and has a value between 0 and 1 . This is the only new term in the storage resource equation (see Section 2) that is not described in Brennan and others (2010).

- $i=1,2$, or 3 and are the names of the residual trapping injectivity classes.

- $R i$ are injectivity class fractions determined from a probabilistic distribution of rock-permeability data. All three $R i$ must sum to one (see Section 4).

The sixth category, $K R R_{S R}$, is calculated separately using known recovery production volumes, buoyant trapping storage efficiency factors, and $\rho_{\mathrm{CO}}$. To help define the input parameters for $T A_{S R}$ and $K R R_{S R}$, additional parameters were estimated by the assessment geologist or the assessment team. Formation volume factors $(F V F)$ for oil, gas, and natural gas liquids are used to convert surface production volumes to equivalent volumes at depth. These were calculated from basin subsurface geothermal gradients and reservoir characteristics (see Section 5). The depth range was determined for each SAU and was important for density, storage efficiency, and formation volume factor calculations (see Section 5).

The Monte Carlo simulation method is a technique to propagate uncertainty from each input parameter through to the calculations of storage resources (see Section 7). The assessment geologists specify a minimum, most likely, and maximum estimate for the mean of each of the input parameters that are then used to define a continuous distribution (see Section 3). The one exception is the injectivity class fractions, $R i$, which are deterministic values in the Monte Carlo simulation, yet are themselves determined from a probabilistic distribution of rock permeability data (see Section 4).

This report addresses details changed from, or not covered in, the original methodology of Brennan and others (2010), including the following:

1. criteria for choosing and classifying SAUs;

2. a description of the new multiplicative factor $\left(R_{W}\right)$ that conforms the assessment to EPA underground sources of drinking water (USDW) water-quality restrictions (U.S. Environmental Protection Agency, 2009, 2010);

3. the statistical distributions chosen for all assessment inputs in the Monte Carlo simulation;

4. a new method to determine the injectivity class fractions $(R i)$ for residual trapping storage resources using rock permeability estimates;

5. the estimation of basin-scale geologic parameters including formation volume factors $(F V F)$, density $\left(\rho_{\mathrm{CO}_{2}}\right)$, and storage efficiencies $\left(B_{S E}\right.$ and $\left.R i_{S E}\right)$;

6. calculation of input parameters related to hydrocarbon production including buoyant trapping pore volume $\left(B_{P V}\right)$ and known recovery production volumes converted to volumes at reservoir conditions $\left(K R_{R E S}\right)$;

7. a description of the Monte Carlo procedures; and

8. a description of the probabilistic aggregation procedures.

\section{Criteria for Choosing and Classifying Storage Assessment Units}

In the Brennan and others (2010, p. 26) methodology, a SAU is a "mappable volume of rock that includes the storage formation, a reservoir flow unit for $\mathrm{CO}_{2}$ storage, and a regional seal formation." The methodology, following EPA regulations, precludes storage in formations with fresh water, defined as having a total dissolved solids (TDS) concentration less than $10,000 \mathrm{mg} / \mathrm{L}$ (milligrams per liter). Water-quality restrictions are addressed twice during the assessment: in the criteria for choosing and classifying SAUs (this section) and in the residual trapping storage resource calculations (see Section 2).

The EPA has an application process to obtain waivers for storage in existing oil and gas reservoirs containing "fresh" water, based on the TDS criterion. Because buoyant trapping storage reservoirs may receive such a waiver, water-quality criteria are only applied to residual trapping storage resources. This means that even if all known formation water is fresh, a formation may still be assessed if it has known or undiscovered (as defined in USGS national oil and gas assessments (NOGA)) oil and gas reservoirs. However, formations are excluded from assessment if all known formation water is fresh and there are no known or undiscovered hydrocarbon reservoirs. This includes regions with nonhydrocarbon-producing structural or stratigraphic traps. If the formation meets these initial criteria for high-salinity water in residual traps, it may be assessed as a SAU if it meets the remaining criteria described in the following paragraph. Section 2 describes how water-quality factors into the residual trapping storage resource calculations. 


\section{STORAGE ASSESSMENT UNIT INPUT DATA FORM \\ Identification Information}

Assessment geologist:

Date:

Assessment region:

Province:

Basin:

Storage Assessment Unit (SAU):

Number:

Number:

Number:

SAU relationship to NOGA AU:

Notes from assessor:

\section{Characteristics of the Storage Assessment Unit}

Lines 1-9 concern data for the SAU at depths of (check one):

$3,000-13,000 \mathrm{ft}$

$>13,000 \mathrm{ft}$

(1) SAU depth from surface (ft):

minimum:

minimum:

minimum:

most likely:

most likely:

most likely:

maximum:

maximum:

maximum:

(4) SAU water quality (check one):

Most of the water in the SAU is saline (greater than $10,000 \mathrm{mg} / \mathrm{L}$ TDS).

Water in this SAU is both saline and fresh.

Most of the water in the SAU is fresh (less than $10,000 \mathrm{mg} / \mathrm{L} \mathrm{TDS}$ ).

(5) Area fraction available for storage (generally, the area where SAU pore water has more than 10,000 mg/L TDS):

minimum

minimum

(6) Mean thickness net porous interval $(\mathrm{ft})$ :

(7) Mean porosity net porous interval (fraction): minimum:

\section{Buoyant Trapping Probabilistic Calculation Inputs}

(8) Buoyant trapping pore volume (MMbbl):

minimum:

most likely:

maximum:

\section{Residual Trapping Probabilistic Calculation Inputs}

(9) Permeability of the net porous interval $(\mathrm{mD})$ : minimum: most likely:

maximum:
Figure 1. U.S. Geological Survey carbon dioxide sequestration assessment input data form for each storage assessment unit. These (SAU) data inputs are used in the calculations described throughout the text and shown in figure 9 . Some of the data inputs are solely descriptive and are not used in the calculations (for example lines 1,3, and 4), although they were helpful in determining other data input parameters. See Abbreviations, Acronyms, and Symbols table for abbreviation descriptions. 
During the assessment, geologists discussed the merits of potential storage formation and regional seal pairs within all major sedimentary basins of the United States and designated them either as (1) assessed SAUs, (2) nonquantitative SAUs, or (3) nonassessed formations. A permanent panel of experienced assessment geologists presided over all assessment meetings and worked with the assessment geologist to arrive at a consensus for the values entered on the assessment forms. Assessed SAUs are those deemed by the assessment panel to have good potential storage, a regional seal, and some saline formation waters. Assessed SAUs are assigned a SAU number, scheduled for inclusion in the geologic framework basin report series (Warwick and Corum, 2012), and the SAU number is included in the final data tables in both the assessment results and assessment data reports. Some formations may have a good potential reservoir, a regional seal, and saline formation water in residual traps, yet there is a lack of data to build a geologic model (fig. 2) that will estimate the storage resource accurately. These are classified as nonquantitative SAUs, and though each has a SAU number and a full geologic evaluation in the geologic framework basin-report series, no results are presented in the assessment results report. Non-assessed formations are those that may not have good reservoir quality, are lacking a good regional seal, or contain solely fresh formation waters outside of buoyant traps. Some nonassessed formations are described in the geologic framework basin-report series, but these are not assigned assessment numbers, and no results are presented in the assessment results report.

\section{Water Quality}

The U.S. Environmental Protection Agency regulations from the Underground Injection Control Program (UIC) for Class VI wells prohibits $\mathrm{CO}_{2}$ injection into underground sources of drinking water (USDW), defined as groundwater with a TDS concentration less than 10,000 mg/L (U.S. Environmental Protection Agency, 2010). In Brennan and others (2010), the SAU boundary was limited in extent, regardless of depth, by the presence of waters with TDS concentrations less than $10,000 \mathrm{mg} / \mathrm{L}$. In practice, defining the specific extent of fresh water for excision from the SAU is complicated. At the basin scale, available water-quality data (for example, Breit,

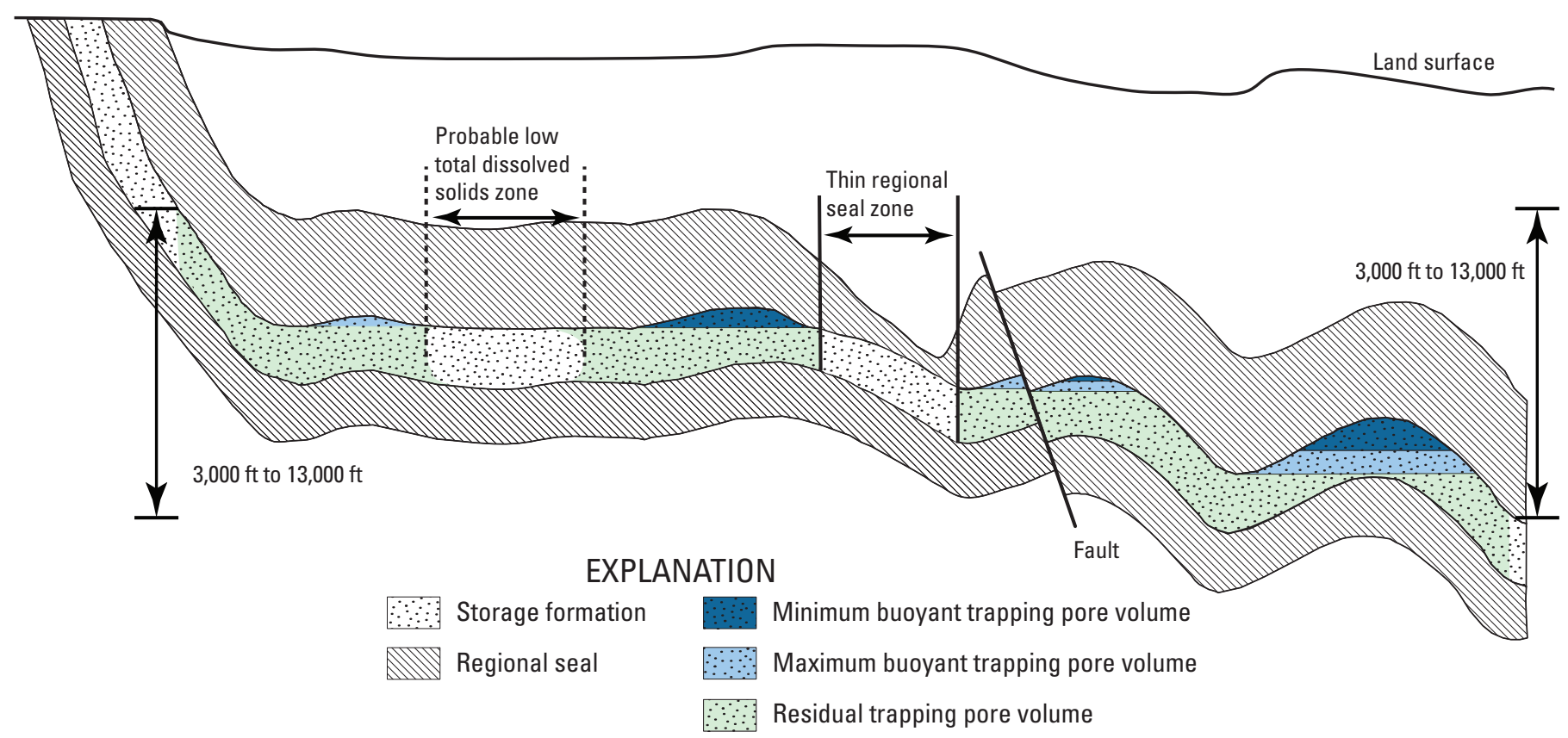

Figure 2. Schematic cross section through a storage assessment unit (SAU) illustrating the relation between buoyant and residual trapping styles in the storage formation. The SAU minimum depth limit criteria of $3,000 \mathrm{ft}$ ensures that carbon dioxide is in a supercritical state to minimize the storage volume, and 13,000 ft is the lower limit accessible with average injection pressures. A deep SAU can be defined for depths greater than $13,000 \mathrm{ft}$ if favorable reservoir conditions exist. The lateral limit of the SAU is defined by the location where the top of the storage formation reaches the defined depth limit. Also shown are zones of probable low total dissolved solids and thin regional seal zones, which may be excluded from a SAU. 
2002; U.S. Department of Energy National Energy Technology Laboratory, 2010) indicate that some formations contain a mix of saline- and fresh-water data. Further, the data are of variable and sometimes unknown quality and do not always exist throughout all SAUs. In the Rocky Mountain region basins, for example, all potential SAUs have at least some fresh-water data among the saline-water data. Under the methodology of Brennan and others (2010), all formations, and therefore this entire region, would be excluded from assessment. To address this problem, a modified concept of SAU creation was employed so that the salinity of the formation waters is no longer factored into delineating the SAU boundary. Instead, the USGS now uses a factor range $(0-1)$ to account for the fresh-water fraction and accordingly reduce the total amount of the residual trapping storage resource. Note that the following procedure is only used if the formation was not excluded from assessment for having solely fresh water in residual trapping regions (see Section 1).

To capture water quality and related restrictions, two lines were added to the Brennan and others (2010) assessment input form (fig. 1); line 4 is a classification or qualitative description of the average water quality in the SAU, and line 5 is the input for a minimum, most likely, and maximum fraction of the SAU that is available for storage. The possible distributions assigned to this input range are described in Section 3. Generally, the minimum fraction is the area immediately surrounding the SAU including known saline data points. The maximum fraction is the area remaining after excluding regions with fresh-water data points but including regions of no data. The most likely value is the assessment geologist's best estimate given the water-quality data, basin structure, and groundwater maps. For example, consider a SAU that contains a clearly saline-water interval that accounts for 50 percent of its volume, a fresh-water interval that accounts for 30 percent of its volume, and has poor data availability in 20 percent of the volume. The assessment geologist may conclude that the inputs for line 5 on the assessment form may be a minimum fraction of 0.50 , a most likely of 0.60 , and a maximum of 0.70 (fig. 1). Figure 2 shows a schematic cross section through a SAU from the methodology of Brennan and others (2010) updated to account for this new area fraction.

\section{Distributions}

In the initial methodology by Brennan and others (2010), a lognormal distribution is suggested for the buoyant trapping pore volume and triangular distributions are suggested for all other parameters. The assessment input form also specified the measure of central tendency for each distribution, such as the median or the mode. During the course of the USGS assessment, these options were found to be too restrictive, overestimated the high estimates (for the triangular distributions), and did not accurately represent geological phenomena. In order to facilitate more adaptive interpretation where few data are available or where analogs are implemented, and to allow for more geologically realistic distributions, the choice of distribution is now flexible. The terms mode and median were removed from the form (fig. 1) and replaced with the more general "most likely" term, which becomes the appropriate measure of central tendency for the chosen distribution.

The assessment geologist is free to assign the most applicable distribution shape to the input parameters, though changes from the following suggestions are uncommon. The default distribution for inputs other than the buoyant trapping pore volume and permeability, such as area, porosity, and thickness, is now a Beta-PERT distribution. Beta-PERT distributions are a three-parameter special case of the fourparameter Beta distribution (for example Vose, 1996). Olea (2011) showed that the Beta distribution, with finite minima and maxima like the triangular distribution, can better represent the shape of distributions found in nature such as the normal or the lognormal. The Beta-PERT distribution was found to be a good compromise between the triangular and the Beta distributions because, like the triangular distribution, only three parameters (minimum, MIN; most likely, M.LIKELY; and maximum, $M A X$ ) must be specified, but it can still mimic distributions typical for geologic data like the Beta, normal, and lognormal distributions. The two shape parameters, $\alpha_{1}$ and $\alpha_{2}$ for the Beta-PERT distribution used in the @ Risk software (Palisade Corporation, 2010), are defined as

$$
\begin{aligned}
& \alpha_{1}=6\left[\frac{\mu_{\text {Beta-PERT }}-M I N}{M A X-M I N}\right] \\
& \alpha_{2}=6\left[\frac{M A X-\mu_{\text {Beta-PERT }}}{M A X-M I N}\right]
\end{aligned}
$$

where the mean is

$$
\mu_{\text {Beta-PERT }}=\frac{M I N+4 M \cdot L I K E L Y+M A X}{6} .
$$

The updated methodology continues to use a defaulttruncated lognormal distribution for buoyant pore volume $\left(B_{P V}\right)$ and for permeability in the injectivity class $(R i)$ calculation (see Section 4). The minimum, most likely, and maximum estimates are converted to a truncated lognormal distribution for $B_{P V}$ and $R i$ by the following procedure. The mean, $\mu$, and standard deviation, $\sigma$, of a normal distribution in log space are

$$
\begin{gathered}
\mu=\ln (M . L I K E L Y-M I N) \\
\sigma=\frac{\ln (M A X-M I N)-\mu}{Z}
\end{gathered}
$$

where MIN, M.LIKELY, and MAX are the input parameters defined by the assessment geologist and $\mathrm{Z}$ is the critical value, or inverse normal probability function, for a particular 
confidence interval (Attanasi and Charpentier, 2007). For example, if the assessment geologist claims that there is only a 1/1,000 chance that the maximum estimate may be exceeded, then one half of the distribution (the full range, $\ln (M A X-M I N)$, minus the mean, $\mu)$ must fall within $Z=3.09$ standard deviations, $\sigma$, from the mean. For less sure $1 / 100$ and $1 / 10$ chances, $Z=2.33$ and 1.28 , respectively.

The transformation to a truncated lognormal distribution in linear space that conforms to the assessment geologist's minimum, most likely, and maximum inputs (Aitchison, 1986) is

$$
\begin{gathered}
\text { mean }=e^{\mu+\frac{1}{2} \sigma^{2}} \\
\text { s.d. }=\sqrt{e^{2 \mu} e^{\sigma^{2}}\left(e^{\sigma^{2}}-1\right)} .
\end{gathered}
$$

These two parameters from equations 7 and 8 are then used to generate a truncated lognormal distribution that represents the buoyant trapping pore volume or permeability.

\section{Injectivity Classes}

In Brennan and others (2010), total residual $\mathrm{CO}_{2}$ storage is divided into three injectivity classes based on intrinsic rock permeabilities, $k$, where

$$
\begin{aligned}
& \text { class } 1: k>1 \mathrm{D} \text { (darcy) } \\
& \text { class 2: } 1 \mathrm{mD} \text { (millidarcy) }<k<1 \mathrm{D} \\
& \text { class 3: } k<1 \mathrm{mD}
\end{aligned}
$$

These injectivity classes, which commonly were applied inconsistently among the assessment geologists, were the only deterministic inputs in a probabilistic assessment and did not reflect the reservoir permeability distribution as indicated by available data and analogs. Instead of using these deterministic percentage inputs, the assessment geologist now specifies a minimum, most likely, and maximum estimate of permeability, just as is done for all other parameters (for example area, porosity, and thickness). These estimates are used to define a truncated lognormal distribution (equations 5 through 8) that represents permeability. The percentage of the permeability distribution that falls into each of the three permeability classes is calculated from the cumulative probability of the distribution, truncated at the minimum and maximum values. Figure 3 shows an example in which the minimum permeability estimate is $0.1 \mathrm{mD}$, the most likely estimate is 100 $\mathrm{mD}$, and the maximum estimate is $4,000 \mathrm{mD}$. The cumulative probability of the lognormal distribution created following equations 5 through 8 and truncated by the minimum and maximum estimates is shown as the black curve. Thus the cumulative probability $\left(\mathrm{P}_{k}\right)$ at $1 \mathrm{mD}, \mathrm{P}_{k}(1 \mathrm{mD})$, is equal to the percentage of class 1 rocks (equation 9). The remaining equations to determine cumulative probability and injectivity class are shown in equation 9.

$$
\begin{aligned}
& \text { class } 1=1-P_{k}(1 \mathrm{D}) \\
& \text { class } 2=P_{k}(1 \mathrm{D})-P_{k}(1 \mathrm{mD}) \\
& \text { class } 3=P_{k}(1 \mathrm{mD})
\end{aligned}
$$

In the figure 3 example, five percent of the permeability distribution is less than $1 \mathrm{mD}$, the class 3 fraction. Eightytwo percent of the permeability distribution falls between 1 $\mathrm{mD}$ and 1 Darcy, the class 2 fraction. Thirteen percent of the permeability distribution lies above 1 Darcy, the class 1 fraction. These fractions are then used as the deterministic inputs described in Brennan and others (2010). For each Monte Carlo iteration, the total residual area is split into the three classes specified by equation 9 (see Section 7).

\section{Basin-Scale Geologic Parameters}

Formation volume factors are unitless volume multipliers commonly used in the oil and gas industry to convert the volume of produced hydrocarbons at the surface to the volume of those hydrocarbons at the depth from which they were produced. This parameter is necessary when estimating the potential $\mathrm{CO}_{2}$ storage volume of buoyant traps in the subsurface; the space available to store $\mathrm{CO}_{2}$ in a buoyant trap is generally at least as large as what has already been produced. $\mathrm{FVF}_{\mathrm{OIL}}, \mathrm{FVF}_{\mathrm{GAS}}$, and $\mathrm{FVF}_{\mathrm{NGL}}$ (natural gas liquids) are estimated from empirical equations that simplify a complex dependence on pressure, temperature, gas to oil ratio (GOR), and the densities of multiple phases (Verma, 2012; Jahediesfanjani, written commun., 2012). Using production data for individual basins (Nehring Associates, Inc., 2010), plots of $\mathrm{FVF}_{\mathrm{OIL}}, \mathrm{FVF}_{\mathrm{GAS}}$, and $\mathrm{FVF}_{\mathrm{NGL}}$ versus depth were created for each basin where these data existed. An example for the Uinta and Piceance Basins is shown in figure 4 . From each plot, the minimum, most likely, and maximum $F V F$ s are estimated for a given basin for the depth range of each SAU and fit to a Beta-PERT distribution (see Section 3). Formation volume factors are applied in the calculations that help estimate the buoyant trapping pore volume inputs, $B_{P V}$ (see Section 6.1) and the known recovery-replacement storage resource, $K R R_{S R}$ (see Section 6.2).

\subsection{Density}

The USGS methodology requires that a "probabilistic distribution of the density of $\mathrm{CO}_{2}$ is calculated by the assessment team based on the upper and lower depth boundaries of the SAU, temperature and pressure gradients 


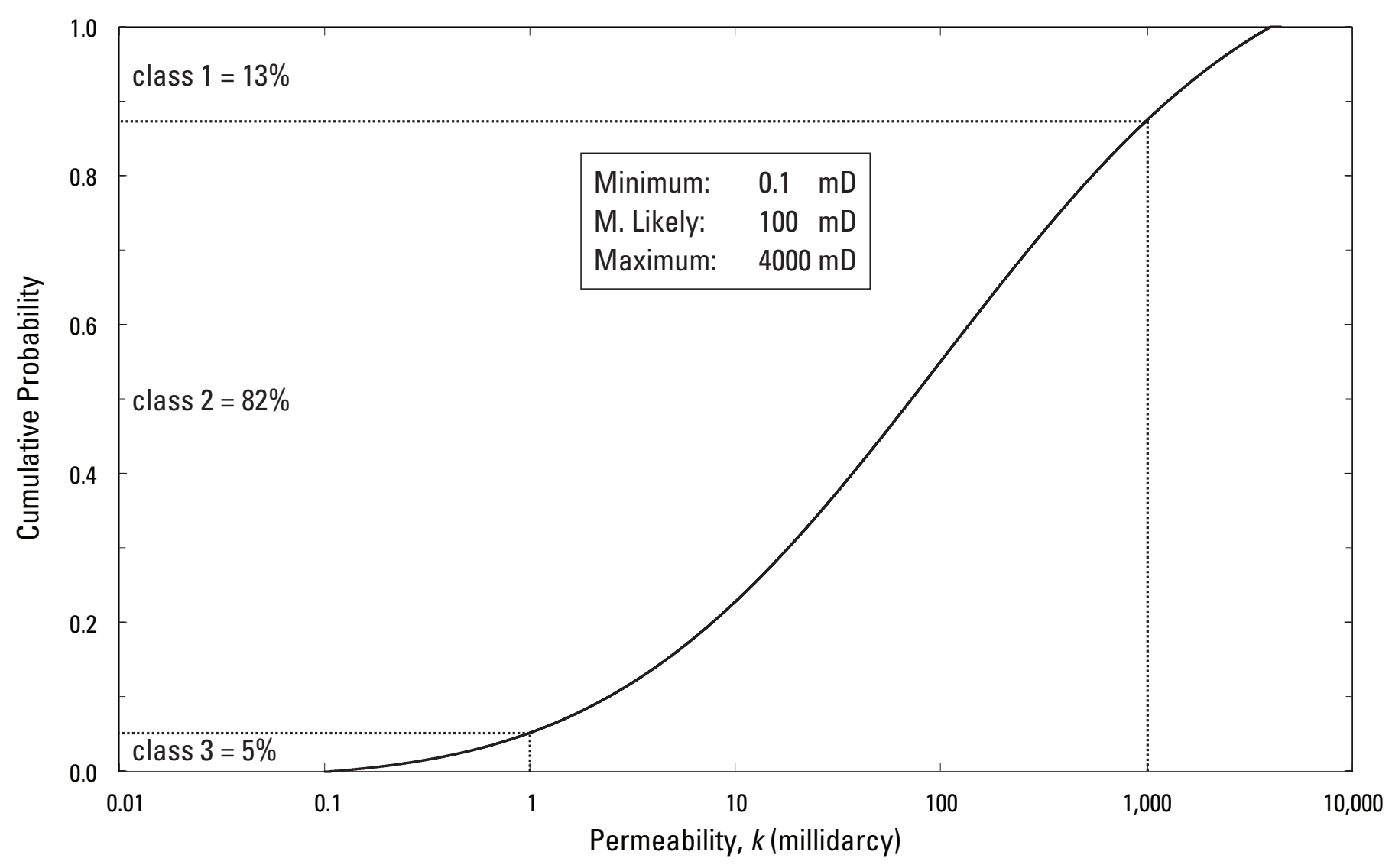

Figure 3. Injectivity classes. The black curve is the cumulative probability for a truncated lognormal distribution with mean and standard deviation calculated from the inset minimum, most likely (M. Likely), and maximum permeabilities. The dotted lines represent the cumulative probabilities at 1 millidarcy and 1,000 millidarcy. Five percent of the data are less than 1 millidarcy, so 5 percent of the total residual trapping storage for this SAU is in class 3,82 percent is in class 2, and 13 percent is in class 1.

appropriate for the area, and an equation of state for $\mathrm{CO}_{2}$ " (Brennan and others, 2010, p. 11). The density distribution is needed to compute the known recovery production volumes converted to volumes at reservoir conditions $\left(K R_{R E S}\right)$ and to convert all calculated storage volumes to mass of $\mathrm{CO}_{2}$ that can be stored within those volumes (storage resources). When converted to mass, the assessment results may be easily compared to other published estimates of $\mathrm{CO}_{2}$ storage in billion metric tons, such as the North American Carbon Sequestration Atlas (U.S. Department of Energy, National Energy Technology Laboratory, 2012). This section describes the prediction of basin-scale density conditions that are appropriate for geologic $\mathrm{CO}_{2}$ sequestration.

In the USGS assessment, $\mathrm{CO}_{2}$ density values are computed from subsurface geothermal gradients. The geothermal gradient expresses the average subsurface temperature change, which typically increases in sedimentary basins by about 30 degrees Celsius per kilometer $\left({ }^{\circ} \mathrm{C} / \mathrm{km}\right)$ below the ground surface or sea bed (Holloway, 2001). However, there exist considerable variations in geothermal conditions both within basins and between basins. In the pore spaces of sedimentary rocks, the pressure commonly increases along the hydrostatic gradient, which is the pressure generated by a column of water of height equal to the depth of the SAU pore space. This relation holds because the pore space is mostly filled with water and may be connected along a complex path to the surface (Holloway, 2001). Nevertheless, when the pore space is disconnected, the pressure may be greater than the predicted hydrostatic gradient pressure and result in overpressure of the SAU. The opposite condition, underpressure, may also exist, either naturally or as a result of fluid withdrawals. However, the required large-scale resolution of the current assessment necessitates the determination of basinaveraged gradients that do not account for local variations in pressure from the mean trend. Therefore, for the purposes of basin-scale density estimates, overpressure and underpressure are ignored.

Cross plots of pressure and temperature data are generated for coincident depths and plotted against warm, critical, 

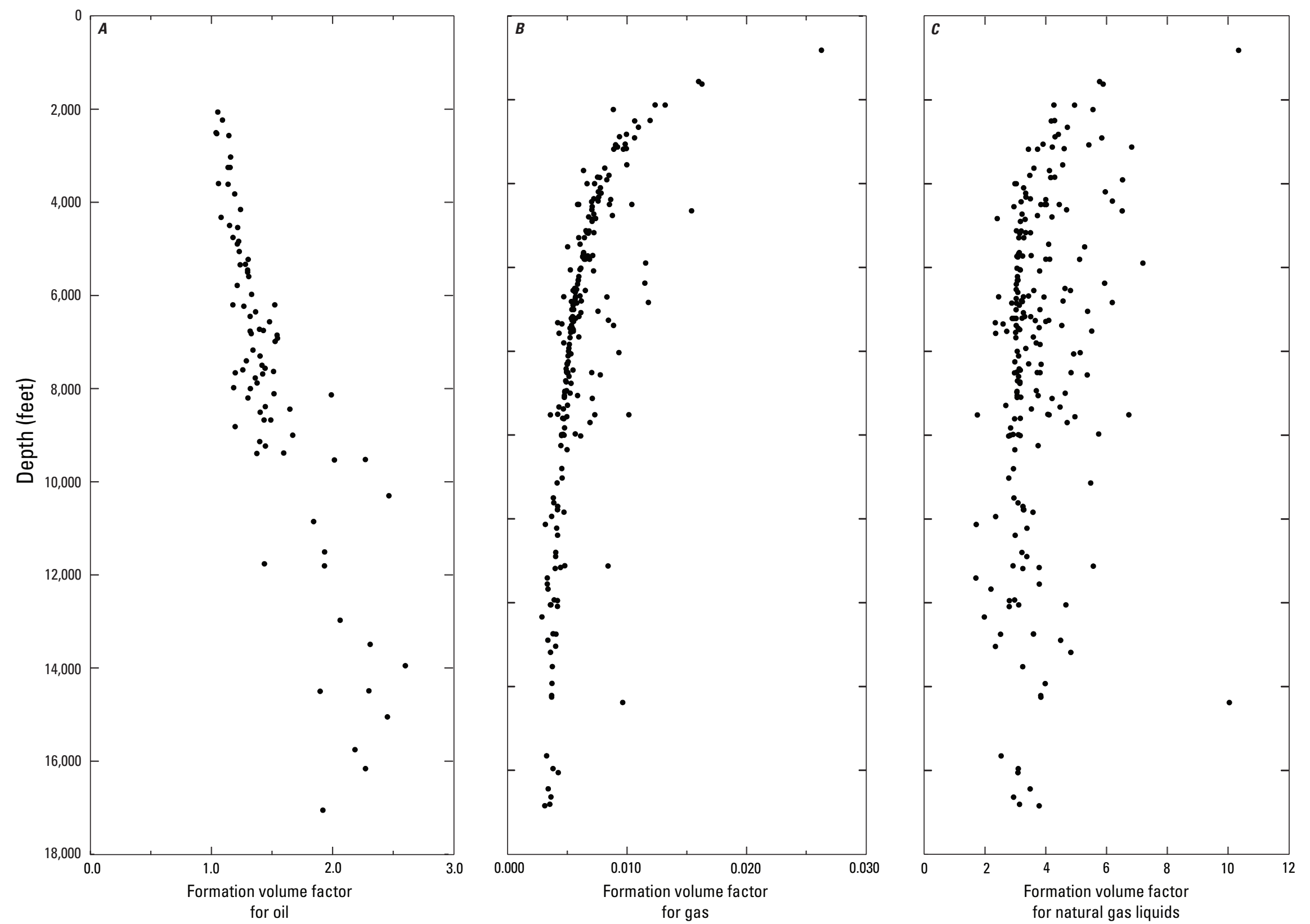

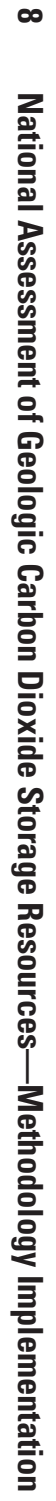

Figure 4. Formation volume factors versus depth for the Uinta and Piceance Basins. The data represent formation volume factor calculations for the Uinta and Piceance Basins derived from Nehring Associates, Inc. (2010). The three panels show $(A)$ Formation volume factor of oil, $(B)$ Formation volume factor of gas, and $(C)$ Formation volume factor of natural gas liquids as a function of depth. The minimum, most likely, and maximum values for a given storage assessment unit (SAU) are estimated from the average values for the appropriate range of SAU depths. 

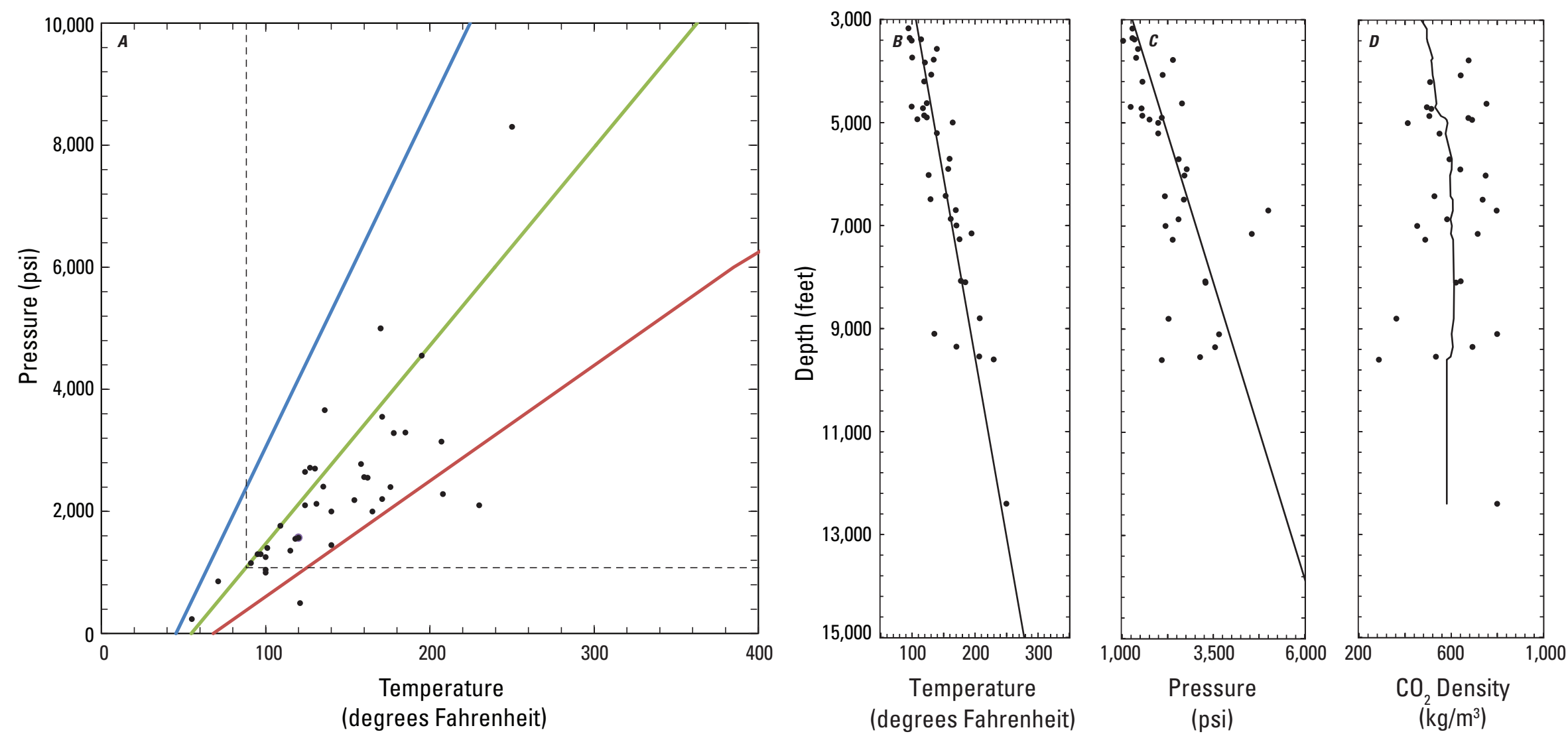

Figure 5. Carbon dioxide $\left(\mathrm{CO}_{2}\right)$ density versus depth for the Uinta and Piceance Basins. All plots use data from Nehring Associates, Inc. (2010). (A) Pressure versus temperature. The pressure and temperature limits (1,070 pounds per square inch (psi) and $88^{\circ} \mathrm{F}$ (degrees Fahrenheit)) above which $\mathrm{CO}_{2}$ is super critical is also shown with dotted gray lines. Geothermal gradients for warm (red), critical (green), and cool (blue) world basins (Bachu, 2003) are shown. ( $B$ ) Temperature versus depth. A geothermal gradient line is also shown for a temperature gradient of $1^{\circ} \mathrm{F}$ per 70 feet of depth and a surface temperature of $64^{\circ} \mathrm{F}$. $(\mathrm{C})$ Pressure versus depth plot. A hydrostatic gradient line is also shown for a pressure gradient of $0.433 \mathrm{psi} / \mathrm{ft}$. (D) Density versus depth using pressure and temperature inputs from figures $5 A$ and $5 B$. The black curve is a moving average. $\mathrm{kg} / \mathrm{m}^{3}$, kilograms per cubic meter. 
and cool trend lines for world basins (Bachu, 2003) (figs. $5 \mathrm{~A}$ and $6 \mathrm{~A}$ ). Where possible, reservoir average pressure and temperature values from the "Significant Oil and Gas Fields of the United States Database" (Nehring Associates, Inc., 2010) are used as the inputs to the equation of state calculations. In basins lacking Nehring Associates, Inc. (2010) data, data from the proprietary IHS Energy Group (2010) database are used instead. The IHS dataset contains welltemperature data but lacks significant amounts of pressure data, so a standard hydrostatic gradient $(0.433$ pounds per square inch per foot (psi/ft)) is assumed where pressure data do not exist. The distribution of the points on the warm or cool basin side is checked against maps from the geothermal gradient of North America project (Blackwell and others, 1991; Blackwell and Richards, 2004). The subsurface supercritical $\mathrm{CO}_{2}$ density is then calculated using the $\mathrm{CO}_{2}$ equation of state (Span and Wagner, 1996; Lemmon and others, 2010). The results include plots of supercritical $\mathrm{CO}_{2}$ density with depth for the U.S. basins or larger regions investigated in our assessment (figs. 5 and 6). Before they are applied to the assessment results, the USGS-computed densities are compared to published trends of $\mathrm{CO}_{2}$ density with depth (Ennis-King and Paterson, 2001; Bachu, 2003; May and others, 2009) and to $\mathrm{CO}_{2}$ density maps, such as those for the Appalachian Basin Oriskany Formation (Dilmore and others, 2008).

Probabilistic distributions of $\mathrm{CO}_{2}$ density, with a minimum, most likely, and maximum value are chosen along the spread of data based on the minimum, most likely, and maximum depths determined by the assessment geologist for each $\mathrm{SAU}$ in a basin. Below are two examples of subsurface $\mathrm{CO}_{2}$ density prediction from the Uinta and Piceance Basins and the Appalachian Basin assessments. The Uinta and Piceance Basins are warm basin examples with Nehring pressure and temperature data, whereas the Appalachian is a cool basin example with IHS data only (figs $5 A$ and $6 A$, respectively). Temperature versus depth plots are shown in figures $5 B$ and $6 B$. Pressure versus depth plots are shown in figures $5 C$ and $6 \mathrm{C}$. The supercritical $\mathrm{CO}_{2}$ density calculated for each temperature and pressure data pair using the $\mathrm{CO}_{2}$ equation of state (Span and Wagner, 1996) is shown in figures $5 D$ and $6 D$. For the warm Uinta and Piceance Basins examples, consider a SAU with minimum, most likely, and maximum depths of 3,000 ft, 7,000 ft, and 13,000 ft, respectively. The corresponding minimum, most likely, and maximum $\mathrm{CO}_{2}$ density estimated from figure $5 D$ would be approximately 500 kilograms per cubic meter $\left(\mathrm{kg} / \mathrm{m}^{3}\right), 600 \mathrm{~kg} / \mathrm{m}^{3}$, and 700 $\mathrm{kg} / \mathrm{m}^{3}$, respectively. For the cool Appalachian Basin example, consider a SAU with a minimum, most likely, and maximum depths of 3,000 ft, 7,000 ft, and 9,500 ft, respectively. The corresponding minimum, most likely, and maximum $\mathrm{CO}_{2}$ density estimated from figure $6 D$ would be about $760 \mathrm{~kg} / \mathrm{m}^{3}$, $770 \mathrm{~kg} / \mathrm{m}^{3}$, and $780 \mathrm{~kg} / \mathrm{m}^{3}$, respectively. Similar plots are generated for each basin, and density inputs are chosen for each SAU. For basins where no data or gradients are published, the assessment geologist relies on analogs.

\subsection{Storage Efficiencies}

\subsubsection{Residual Trapping Storage Efficiencies}

A component necessary to estimate $\mathrm{CO}_{2}$ storage is typically referred to as storage efficiency, defined as the fraction of accessible pore volume that will be occupied by injected $\mathrm{CO}_{2}$. Storage efficiency may be estimated in a number of ways but is a function of temperature; pressure; time; lithology and rock properties; multiphase flow parameters such as relative viscosities, densities, and permeabilities for $\mathrm{CO}_{2}$ and water; formation morphology; and assumptions of injection, plume migration, and trapping models. For this assessment, the USGS must determine the storage resource of the residual and buoyant traps separately because they have very different trapping models and thus storage efficiencies. Residual trapping storage efficiencies are determined separately for each of the injectivity classes (see Section 4).

Attempts to define and estimate the residual trapping storage efficiency began with the numerical models of van der Meer (1995). Gorecki and others (2009) and the International Energy Agency (IEA) Greenhouse Gas R\&D Programme (2009) released a comprehensive report on storage efficiency as a function of lithology for the time at which $\mathrm{CO}_{2}$ injection stopped but while the $\mathrm{CO}_{2}$ plume was still mobile. Szulczewski and others (2012) estimated efficiency numerically for both migration-limited and pressure-limited scenarios. Juanes and others (2010), MacMinn and others (2010), and Okwen and others (2010) developed postinjection, post-plume migration, and post-imbibition (when water re-enters the pore space after $\mathrm{CO}_{2}$ plume migration) storage efficiency models for capillary trapping. For the national assessment, the USGS is evaluating the long-term, steady-state storage resource and, therefore, must determine appropriate post-migration and post-imbibition residual trapping storage efficiencies. It is also assumed that all injection projects will be engineered in such a way to optimize storage efficiency and $\mathrm{CO}_{2}$ sweep efficiency (the percentage of the rock or pore space that the nonwetting phase passes through), while avoiding $\mathrm{CO}_{2}$ leakage from the storage formation. Thus, the impact of plume and formation morphology can be neglected in the storage efficiency calculations, and postimbibition capillary trapping models best estimate residual trapping storage efficiencies relevant to the USGS $\mathrm{CO}_{2}$ sequestration assessment.

The MacMinn and others (2010) model can be used to estimate the residual trapping storage efficiency of a sloped reservoir where the interface between the storage formation and the sealing formation is not horizontal. Using the MacMinn and others (2010) model, the residual trapping storage efficiency due to capillary trapping of an entire SAU can be estimated given temperature and pressure gradients, depth ranges, and estimates of the irreducible water saturation at the leading edge of a mobile $\mathrm{CO}_{2}$ plume, the residual gas saturation at the trailing edge of the plume, and the relative permeability between the $\mathrm{CO}_{2}$ and the connate water. 

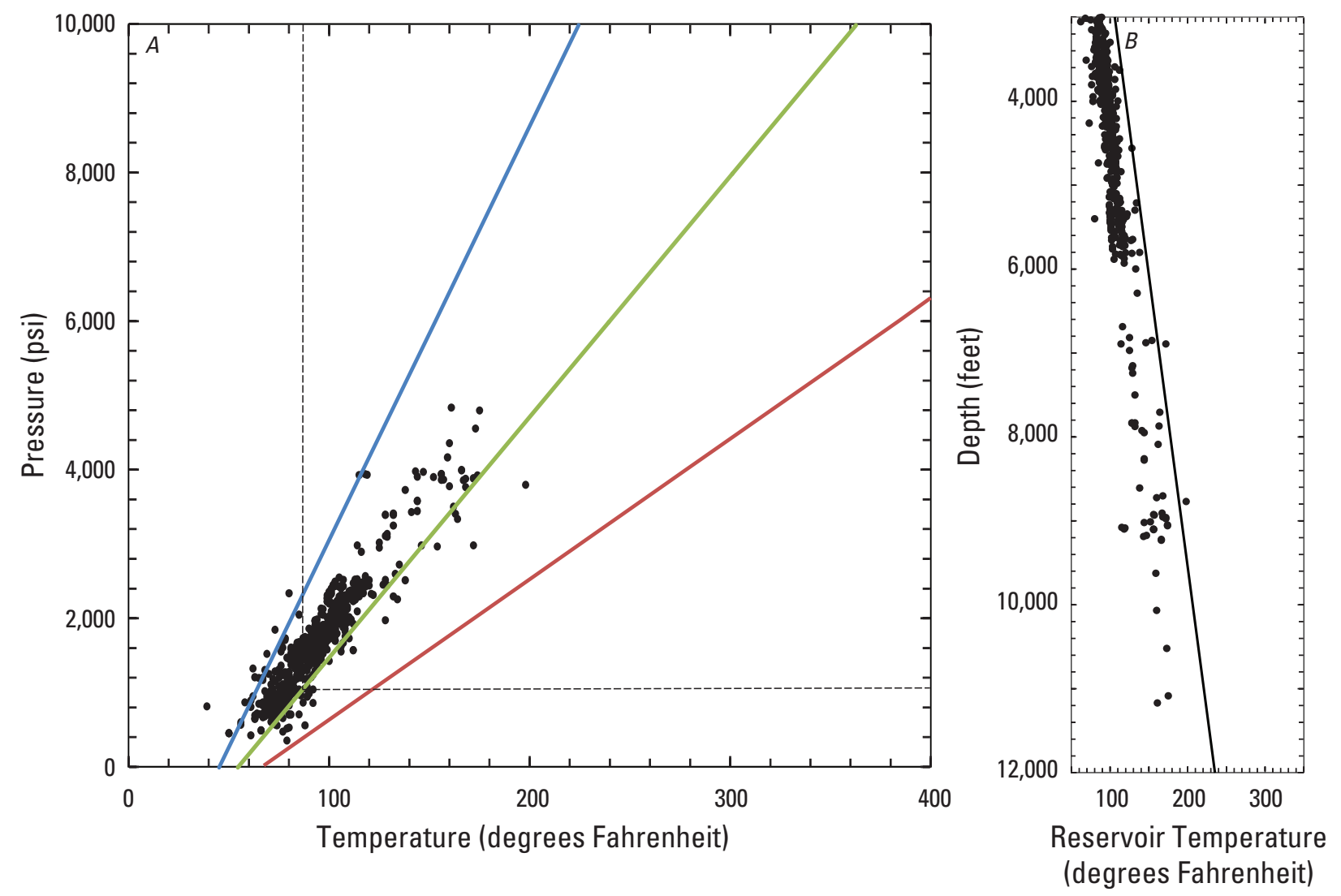

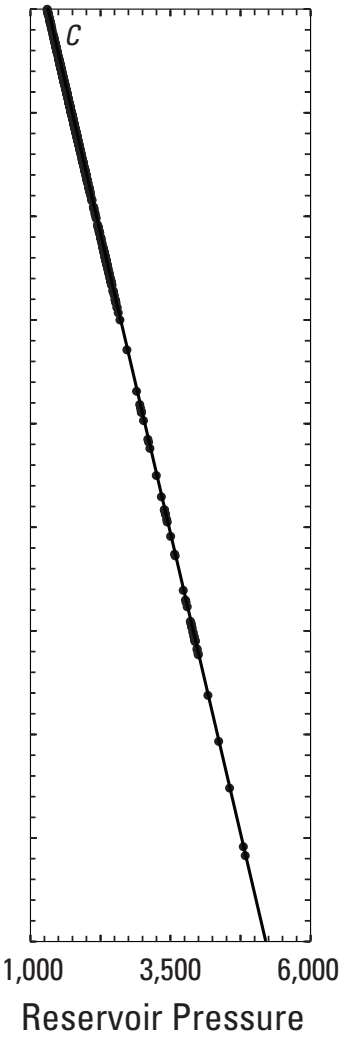

(psi)

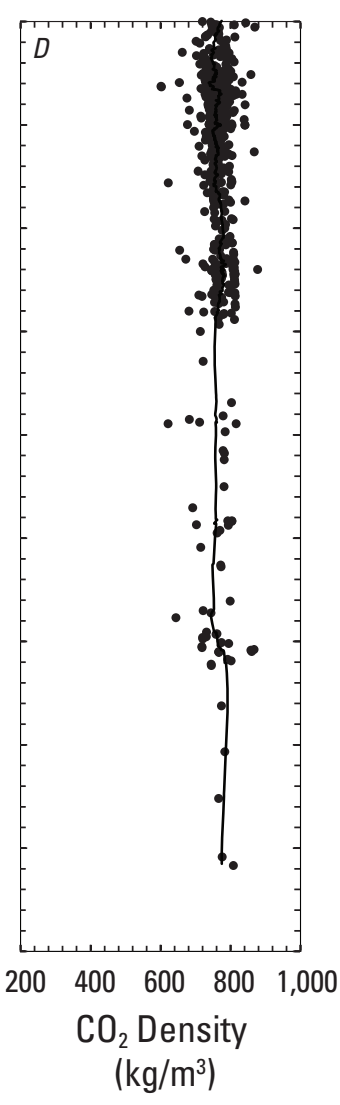

Figure 6. Carbon dioxide $\left(\mathrm{CO}_{2}\right)$ density versus depth for the Appalachian Basin. All plots use IHS Energy Group (2010) data. $(A)$ Pressure versus temperature. The pressure and temperature limits (1,070 pounds per square inch (psi) and $88^{\circ} \mathrm{F}$ (degrees Fahrenheit)) above which $\mathrm{CO}_{2}$ is super critical is also shown with dotted gray lines. Geothermal gradients for warm (red), critical (green), and cool (blue) world basins (Bachu, 2003) are shown. (B) Temperature versus depth. A geothermal gradient line is also shown for a temperature gradient of $1^{\circ} \mathrm{F}$ per 70 feet of depth and a surface temperature of $64^{\circ} \mathrm{F}$. (C) Pressure versus depth plot. A hydrostatic gradient line is also shown for a pressure gradient of $0.433 \mathrm{psi} / \mathrm{ft}$. (D) Density versus depth using pressure and temperature inputs from figures $6 A$ and $6 B$. The black curve is a moving average. $\mathrm{kg} / \mathrm{m}^{3}$, kilograms per cubic meter. 
The storage efficiency equation of MacMinn and others (2010) also allows for the estimation of storage efficiency uncertainty, important for the probabilistic assessment, using ranges of input parameters and plotting the output values versus depth. The approximation equation of MacMinn and others (2010) for capillary trapping post-migration, postimbibition storage efficiency, $\varepsilon_{s}$, is

$$
\varepsilon_{S}=\Gamma^{2} /[0.9 M+0.49]
$$

where $\Gamma$ is the capillary trapping number and $M$ is the mobility factor. The capillary trapping number is defined as

$$
\Gamma=\frac{S_{g r}}{1-S_{w c}}
$$

where $S_{g r}$ is the residual gas saturation after imbibition and $S_{w c}$ is the connate water saturation, or irreducible water saturation (MacMinn and others, 2010). The mobility factor, derived from MacMinn and others (2010) is

$$
M=k_{r g} \mu_{w} / \mu_{g}
$$

where $k_{r g}$ is the relative permeability of the mobile $\mathrm{CO}_{2}$ phase with a value between zero and one, $\mu_{\mathrm{g}}$ is the viscosity of $\mathrm{CO}_{2}$, and $\mu_{w}$ is the viscosity of water. Equation 12 is valid under the assumption whereby the mobility in the reservoir region containing residually trapped $\mathrm{CO}_{2}$ is equal to the mobility in the reservoir region that contains the mobile $\mathrm{CO}_{2}$ plume. The mobility factor in the efficiency equation approximates fluid flow of a nonwetting fluid phase that is similar to the term "sweep efficiency" in enhanced oil recovery parlance. The sweep efficiency is an estimate of how much of a porous medium will be invaded by the nonwetting phase.

The values of $k_{r g}, S_{g r}$, and $S_{w c}$ are taken from experimental work (Bennion and Bachu, 2005, 2008; Burton and others, 2008; Okabe and Tsuchiya, 2008; Okabe and others, 2010) and modeling efforts (Kopp and others, 2009a,b; Juanes and others, 2010; Okwen and others, 2010; Szulczewski and others, 2012). This method is used to calculate residual trapping storage efficiencies for class 1 and class 2 rocks. The procedure for class 3 rocks is described below. The values that are chosen for class 1 inputs are $=0.6, S_{g r}=$ 0.25 , and $S_{w c}=0.4$, and for class 2 inputs are $=0.6, S_{g r}=0.3$, and $S_{w c}=0.4$. The class 1 value for $S_{g r}$ is slightly lower based on the assumption that less $\mathrm{CO}_{2}$ would be trapped during imbibition in high permeability rocks. Higher permeability rocks have fewer instances of "snap off," where a portion of a nonwetting phase becomes disconnected from the mobile phase, typically along the trailing edge of a plume. The viscosities of $\mathrm{CO}_{2}$ and water were calculated from temperature and pressure data from petroleum reservoirs within the United States (Nehring Associates, Inc., 2010) using the equation of state by Span and Wagner (1996) for $\mathrm{CO}_{2}$, Wagner and Pruss (2002) for pure water, and Mao and Duan (2008) for brines. The Mao and Duan (2008) model determines the viscosity of water with varying molalities of sodium chloride $(\mathrm{NaCl})$, which is used as a proxy for the viscosity of more complex brines. Because salinity data for each petroleum field were not available, and an average salinity value was assumed for each basin and used for each storage efficiency calculation within that basin, average salinity values were estimated by the assessment geologist using available salinity data.

Residual trapping storage efficiencies (equation 10) for injectivity class 1 and 2 rocks are then calculated for the temperatures and pressures of each petroleum reservoir within each basin (Nehring Associates, Inc., 2010). These values are then plotted versus depth for each basin to estimate the range of potential storage efficiencies at different depth ranges (fig. 7). A sensitivity analysis showed that withinbasin storage efficiency factor variation is much greater than variation resulting from considering different lithologies or basin geotherms. Therefore, following a similar procedure to the formation volume factors and densities, the storage efficiency factors are determined from the basin efficiency factor versus depth plot for the specific depth ranges for each SAU. Separate efficiency factor versus depth profiles were created for injectivity class 1 and class 2 storage efficiencies, which have different assumptions of residual gas saturation, as described above (fig. 7). Minimum, most likely, and maximum estimates of the mean were subjectively chosen from these plots at the appropriate depths for the SAU. Class 3 minimum and most likely storage efficiencies were both assumed to be zero, and the maximum was assigned to be the same as the class 2 most likely estimate. All storage efficiencies are modeled as Beta-PERT distributions unless otherwise specified.

\subsubsection{Buoyant Trapping Storage Efficiencies}

Buoyant trapping storage efficiency is controlled primarily by the mobility of the $\mathrm{CO}_{2}$, relative to the ambient fluids in the physical trap within the storage formation, and the irreducible water fraction $\left(S_{w c}\right)$. The residual gas value is not important, because the $\mathrm{CO}_{2}$ within the trap will be held in place by the high capillary entrance pressure of the sealing formation that encloses the trap. The $S_{w c}$ value for traps is no different than that of the rest of the storage formation and is typically 0.4 (Bennion and Bachu, 2008). This gives a high value for $\mathrm{CO}_{2}$ storage as 60 percent of the pore space $\left(1-S_{w c}\right)$, but in certain dry natural gas fields the methane concentration is up to 80 percent of the pore space (Keelan and Pugh, 1975). Therefore the maximum amount of $\mathrm{CO}_{2}$ that could be held in a trap is 


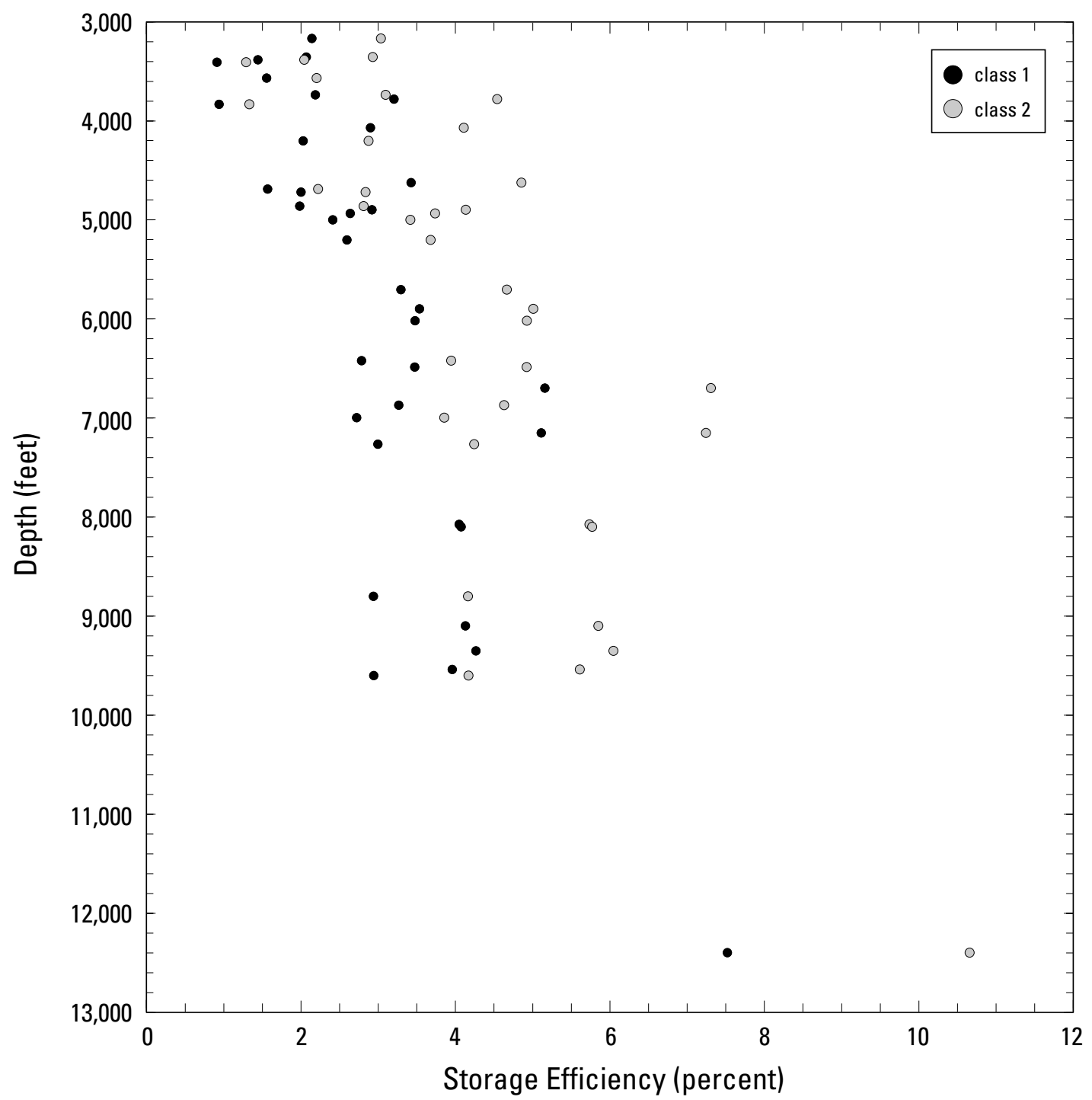

Figure 7. Residual trapping storage efficiency (class 1 and class 2) versus depth for the Uinta and Piceance Basins. The data represent residual trapping storage efficiency calculations derived from Nehring Associates, Inc. (2010) reservoir data from the Uinta and Piceance Basins. Black circles are class 1 storage efficiencies and gray circles are class 2 storage efficiencies. For class 1 rocks, a residual gas saturation of 0.25 was assumed, whereas for class 2 rocks, a residual gas saturation of 0.3 was assumed.

between 60 and 80 percent of the pore space. However, as the sweep efficiency of the injected $\mathrm{CO}_{2}$ will not be 100 percent of the pore space within the trap, the buoyant trapping storage efficiency will be less than 60 to 80 percent of the total pore space. To estimate the buoyant trapping storage efficiency, we have assumed that the mobility of the $\mathrm{CO}_{2}$ will reduce this $1-S_{w c}$ value to approximately 20,30 , or 40 percent, which are the minimum, most likely, and maximum values that are applied to the buoyant pore space of each SAU.

\section{Parameters Related to Hydrocarbon Production}

\subsection{Buoyant Trapping Pore Volume}

The buoyant trapping pore volume distribution defines the amount of $\mathrm{CO}_{2}$ that can be stored through buoyant trapping (Brennan and others, 2010). The assessment geologist may use any available data to determine the distribution, but the 
methodology defines certain default calculations for the minimum and most likely inputs (Brennan and others, 2010). The following sections describe the details of these calculations.

\subsubsection{Minimum}

To determine the buoyant trapping pore volume minimum for a given SAU, one must know the subsurface volume necessary to include all oil, gas, and natural gas liquids that will be produced from existing conventional reservoirs in the formation. Using the national Nehring Associates, Inc. (2010) "Significant Oil and Gas Fields of the United States Database," the known recovery volumes (cumulative production plus reserves) for conventional oil and gas reservoirs were projected (grown) to year 2050 (appendix 1). These grown reservoir volumes were clipped spatially to a given SAU and queried for the formation name. All oil, gas, and condensate volumes were summed independently. The estimated surface volumes were converted to subsurface volumes using formation volume factors (see Section 5.1).

The USGS NOGA assessments (Klett and others, 2005) define oil reservoirs as those with GORs less than 20,000 cubic feet per barrel $\left(\mathrm{ft}^{3} / \mathrm{bbl}\right)$. Gas reservoirs, conversely, have GORs greater than $20,000 \mathrm{ft}^{3} / \mathrm{bbl}$. One cannot simply multiply all gas from both the oil and gas reservoirs by the gas formation volume factor; some of that gas will compress greatly at depth, yet some will dissolve in the oil, increasing the oil volume. This complex behavior is what the formation volume factor simplification targets (Verma, 2012). For gas reservoirs, gas is multiplied by the $\mathrm{FVF}_{\mathrm{GAS}}$, and natural gas liquids are multiplied by the $\mathrm{FVF}_{\mathrm{NGL}}$. For oil reservoirs, only the oil is multiplied by the $\mathrm{FVF}_{\mathrm{OLL}}$. Gas and condensates, though they are often present in oil reservoirs, are not included in the calculation; the volume increase resulting from the dissolution of gas is already covered by the $>1$ oil formation volume factor. The resulting subsurface volumes are converted to the same units (MMbbl) and combined to a single volume distribution for the SAU.

In Nehring Associates, Inc. (2010), some reservoirs have no known recovery data (production plus reserves) specific to producing formations and therefore cannot be included directly in the calculations. This is particularly a problem for certain States (for example Louisiana, Oklahoma, Kansas, and Indiana) where the cumulative production and reserves for a given field are not allocated to individual reservoirs. To resolve this problem to the extent possible, cumulative well production data from the IHS database are used (IHS Energy Group, 2010). Wells from specific fields in the IHS database can be linked to fields from Nehring Associates, Inc. (2010) and the associated list of significant producing reservoirs. Field-specific well production is summed from producing zones corresponding to the producing formations of reservoirs from matched fields in Nehring Associates, Inc. (2010). These field-level sums of cumulative well production by zones can generate ratios used to prorate the Nehring Associates, Inc. (2010) cumulative production values at the field level to the producing formations. The potential growth of these allocated volumes were then calculated for oil, gas, and condensates to the year 2050 (appendix 1) and added to the summed oil and gas production for each SAU.

\subsubsection{Most Likely}

The suggested most likely input for the buoyant trapping pore volume is the sum of the minimum estimate (known recovery at reservoir conditions grown to 2050) and the undiscovered resources estimated by the USGS NOGA assessments (Brennan and others, 2010). The NOGA assessments provide $\mathrm{P}_{5}, \mathrm{P}_{50}, \mathrm{P}_{95}$, and mean values for oil (MMbbl), gas (in billion cubic feet of gas (BCFG)), and natural gas liquids (MMbbl) for all assessment units (AU). Oil reservoirs include oil, gas, and natural gas liquid volumes, and gas reservoirs include gas and natural gas liquid volumes.

A Beta-PERT distribution fit to the $\mathrm{P}_{5}, \mathrm{P}_{50}$, and $\mathrm{P}_{95}$ of the NOGA volumes was then multiplied by the appropriate formation volume factor distribution. Resulting oil, gas, and condensate volume distributions were converted to the same units (MMbbl) and combined to a single volume distribution for each $\mathrm{AU}$. The $\mathrm{CO}_{2}$ assessment geologist then estimated the percentage of any NOGA AU production that was within the SAU. The volume distributions of all relevant AUs, modified by this percentage, were summed to create a final NOGA undiscovered volume distribution for the SAU. Figure 8 shows example distributions for the buoyant minimum and most likely data inputs. The data inputs for the assessment form (fig. 1) are generally the means of these two distributions, although the assessment geologist may choose different values if geologically appropriate.

\subsubsection{Maximum}

The maximum buoyant trapping input is essentially a volumetrically defined input that reflects the full extent of known and predicted buoyant traps in a SAU. General structural geology and the stratigraphic relations between various lithologies in the reservoir formation are the main determinants of the maximum amount of buoyant trapping volume available. Traps described in existing fields provide the most certain evidence for determining the extent of possible buoyant plume storage. These volumes can be derived from structural closure maps and thickness information available in the literature.

In reservoirs where structural traps are not common or where structural data are not present, more predictive methods have been employed by the assessment geologists. The use of analog reservoirs, when properly selected, can provide structural trap sizes from a better known formation in the same basin, possibly one with greater exploration data, or from the same formation but in a similar basin. Using oil and gas field acreages is another method for determining the potential buoyant volume in a reservoir. Because oil and gas generation or charge may be limited within a basin, the geologist may need to project trap size and density outside of the known 


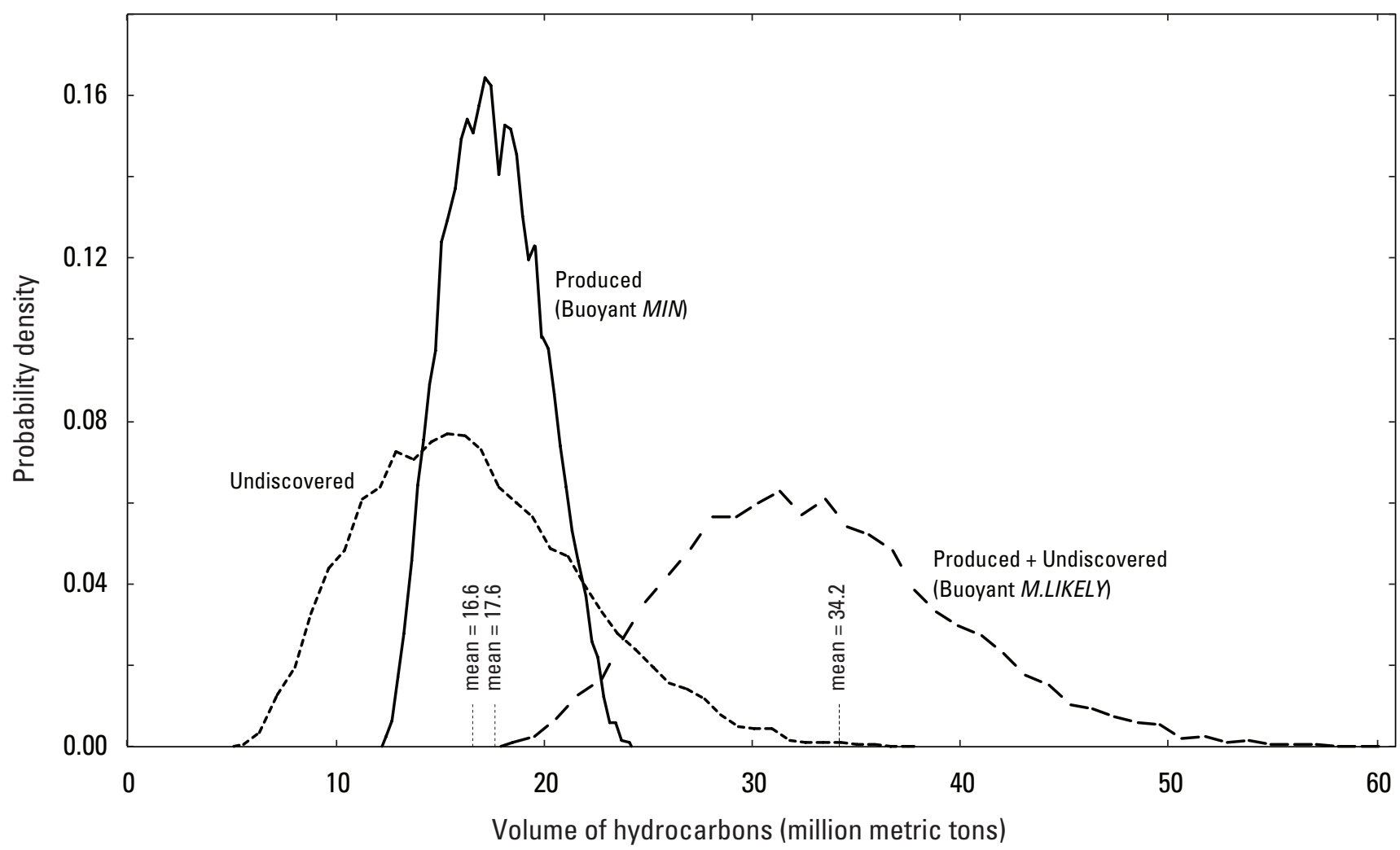

Figure 8. Example buoyant trapping storage probability density plots used to estimate minimum $(M I M)$ and most likely $(M$. LIKELY buoyant trapping storage volume inputs. The tall solid curve represents the volume of produced, grown, oil and gas from a given storage assessment unit (see Section 6.1.1). The mean of this distribution is generally the minimum input for the buoyant calculation (fig. 9A). The short dashed curve on the left is the volume of undiscovered oil and gas in a given SAU (see Section 6.1.2). The sum of the produced and undiscovered curves is shown as the long dashed curve on the right of the figure. The mean of this distribution is generally the most likely input for the buoyant calculation (fig. $9 \mathrm{~A}$ ). The maximum input calculation does not use hydrocarbon volume data and is described in Section 6.1.3.

productive area in the target formation. Though this does add uncertainty to the determination of the input, it may still be the best available method for choosing the input. The goal of the maximum buoyant trapping input is to put a geologically based upper limit on the available volume for storing buoyant $\mathrm{CO}_{2}$ in a SAU. The assessment geologist's task is to determine this value using methods similar to those discussed above, or any other method that is geologically defensible and scientifically sound in the eyes of the assessment review panel.

\subsection{Known Recovery Replacement Storage Resource}

The known recovery replacement storage resource $K R R_{S R}$ is one of the six output categories for the national assessment. As described in the original methodology (Brennan and others, 2010), the $K R R_{S R}$ consists of the known recovery production volumes converted to volumes at reservoir conditions $\left(K R_{R E S}\right)$ multiplied by the buoyant trapping storage efficiency factor, $B_{S E}$, and the $\mathrm{CO}_{2}$ density, $\rho_{C O} . K R_{R E S}$ is calculated similarly to the buoyant minimum. Whereas the buoyant minimum is a single value estimated from the distribution of grown known recovery volumes converted to reservoir conditions using formation volume factors, the $K R_{R E S}$ is this entire distribution. This full distribution is recreated by assigning $\mathrm{P}_{0.1}, \mathrm{P}_{50}$, and $\mathrm{P}_{99.9}$ of the buoyant minimum (fig. 8) to the minimum, most likely, and maximum for the input form. $K R_{R E S}$ is then multiplied by the associated $\mathrm{CO}_{2}$ density and $B_{S E}$ distributions to obtain the $K R R_{S R}$ output.

\section{Monte Carlo Simulation}

For each SAU, the assessment geologist specifies minimum, most likely, and maximum values for the mean of each input parameter over the entire SAU (fig. 1), which are used to define continuous distributions. The one exception is permeability, whose inputs represent a full distribution rather than a 
distribution of the mean. The permeability distribution is not directly used in the volumetric equation, but rather is used to determine injectivity classes (see Section 4), which are the only deterministic inputs in the Monte Carlo simulation. These are agreed upon or changed through consensus of the assessment team. Basin-scale parameters, such as density and storage efficiencies, are calculated separately using the methods described above and are presented as tables in the assessment data report.

Any correlations between input parameters will affect the uncertainty of the final resource distributions. Five parameter pairs were determined to have positive correlations and were given values by expert elicitation (Meyer and Booker, 2001). Porosity $\left(\phi_{P I}\right)$ and permeability (used for the calculation of $R i$ ) are given a correlation coefficient of 0.3 because the data are generally obtained from the same sources. The buoyant trapping pore volume $\left(B_{P V}\right)$ and area of the storage formation $\left(A_{S F}\right)$ are given a correlation coefficient of 0.5 because the larger the SAU area, the greater likelihood for structural and stratigraphic traps, and therefore, the greater probability of a given maximum buoyant trapping volume estimate. The thickness $\left(T_{P I}\right)$, porosity of the net porous interval $\left(\phi_{P I}\right)$, and known recovery production volumes $\left(K R_{R E S}\right)$ are given correlation coefficients of 0.7 with the buoyant trapping pore volume $\left(B_{P V}\right)$ because they are directly used in its calculation. The thicker and more porous a buoyant trap, the more potential exists for buoyant trapping storage volume. Though these values of $0.3,0.5$ and 0.7 were initially chosen as correlation coefficients, it was necessary to adjust these to $0.23,0.38$, and 0.53 , respectively, to create a true positive-definite correlation matrix that could be used in the Monte Carlo simulation. See Blondes and others (in press) for a more detailed discussion of correlation matrices related to the USGS assessment.

Calculation of the $K R R_{S R}, B_{S R}, R 1_{S R}, R 2_{S R}, R 3_{S R}$, and $T A_{S R}$ values is performed using the Monte Carlo method with Palisade @Risk software (Palisade Corporation, 2010).A screen capture of the model spreadsheet is shown in figures $9 A$ and $9 B$. The updated methodology flow chart is shown in figure 10. Each simulation has 10,000 iterations such that each input distribution is sampled 10,000 times using Latin Hypercube sampling, without replacement. All intermediate calculations follow the methodology of Brennan and others (2010) with the exception of the new factor $R_{W}$ applied only to the residual volume (see Section 2).

The parameter symbols used throughout this report are in the far left hand column of figure $9 \mathrm{~A}$. The next columns to the right are the parameter name and the measurement units. The column labeled "Form" shows the number corresponding
Figure 9 (following pages). Monte Carlo model calculations. All inputs are shaded in light blue, constants used throughout the assessment in dark blue, intermediate calculations in gold, and output results in green. Calculation descriptions are in gold text. A detailed description of the model can be found in Section 7. (A) Calculations, including assessment inputs, injectivity class calculations, volume calculations, and output results. $(B)$ Correlation matrix, constants, conversion factors, and results. Calcs, calculations; Corr, correlation matrix; Dist, distribution; Lognorm, lognormal; Z, critical value; Ibs, pounds; $\mathrm{kg} / \mathrm{m}^{3}$, kilograms per cubic meter; megaton, million metric tons. All other abbreviations not defined in figure are in the front part of the report.

to the line on the assessment input form (fig. 1). The remaining input data without a Form number can be found in the assessment data report. For each input parameter, the geologists define minimum (MIN), most likely (M.LIKELY) and maximum $(M A X)$ estimates. These are transformed into distributions (see Section 2) and listed under the column labeled "Dist Type." The expected value of this distribution is found under the column labeled "Distribution." For the lognormal (Lognorm) distributions, the parameters necessary to define the distribution (the mean and standard deviation) are calculated following the procedure outlined in Section 3. The $\mathrm{Z}$ factors, or critical values, necessary for the lognormal distributions are shown in figure $9 \mathrm{~B}$. To divide the residual trapping storage into three injectivity classes, a truncated distribution of permeabilities is used (see Section 4; fig. 3). The $P_{k}(1 \mathrm{mD})$ and $P_{k}(1 \mathrm{D})$ are calculated and used to determine the class 1, 2, and 3 fractions (see Section 4, fig. 3). The fig. $9 A$ "Volume Calculations" section shows the intermediate calculations, all converted to cubic feet. The conversion factors, constants, and correlation matrix are found in figure $9 B$. Finally, the "OUTPUT CATEGORY RESULTS" section (fig. $9 A$ ) shows the final calculations, converted to million metric tons $\mathrm{CO}_{2}$. The values in green are the expected values of the output distribution. The 10,000 values that make up this distribution are used for the aggregation procedure (see Section 8). Summary statistics of these distributions, the $\mathrm{P}_{5}$, $\mathrm{P}_{50}, \mathrm{P}_{95}$, and mean, are also shown in green (fig. $9 \mathrm{~B}$ ) and will be presented in the assessment results report. (U.S. Geological Survey Geologic Carbon Dioxide Storage Resources Assessment Team, in press, a) 


\begin{tabular}{|c|c|c|c|c|c|c|c|c|c|c|c|c|}
\hline Inputs & & Units & Form & Min & M.Likely & Max & & & & & Dist Type & Distribution \\
\hline$\overline{A_{S F}}$ & Area of Storage Formation & Acres & 2 & $2,735,000$ & $3,039,000$ & $3,343,000$ & \multirow[b]{4}{*}{$\mu$} & \multirow[b]{4}{*}{$\boldsymbol{\sigma}$} & \multirow[b]{4}{*}{ mean } & \multirow[b]{4}{*}{ s.d. } & \multirow{2}{*}{$\begin{array}{l}\text { PERT } \\
\text { PERT }\end{array}$} & $3,039,000$ \\
\hline$T_{P l}$ & Thickness of Net Porous Interval & $\mathrm{ft}$ & 6 & 30 & 5 & 0 & & & & & & 53 \\
\hline$\Phi_{P l}$ & Porosity of Net Porous Interval & Fraction & 7 & 0.10 & 0.15 & 0.20 & & & & & \multirow{4}{*}{$\begin{array}{c}\text { PERT } \\
\text { PERT } \\
\text { Lognorm } \\
\text { PERT }\end{array}$} & 0.15 \\
\hline$R_{w}$ & Area fraction of SAU that is acceptable (e.g. W0) & Fraction & 5 & 0.00 & 0.00 & 0.18 & & & & & & 0.03 \\
\hline$B_{P V}$ & Buoyant Trapping Pore Volume & MMbbls & \multirow[t]{7}{*}{8} & 1,230 & 1,330 & 2,000 & 4.6 & 0.7 & 124 & 92 & & 1,354 \\
\hline$K R_{R E S}$ & Known Reserves & MMbbls & & 912 & 1,226 & 1,623 & \multirow[b]{6}{*}{$\mu$} & & \multirow[b]{6}{*}{ mean } & \multirow[b]{6}{*}{ s.d. } & & 1,239 \\
\hline$\rho_{\mathrm{CO}_{2}}$ & $\mathrm{CO}_{2}$ Density $\left(\mathrm{kg} / \mathrm{m}^{3}\right)$ & $\mathrm{kg} / \mathrm{m}^{3}$ & & 610 & 690 & 790 & & & & & \multirow{5}{*}{$\begin{array}{l}\text { PERT } \\
\text { PERT } \\
\text { PERT } \\
\text { PERT } \\
\text { PERT }\end{array}$} & 693 \\
\hline$R 1_{S E}$ & class I Residual Trapping Efficiency & Fraction & & 0.020 & 0.041 & 0.052 & & & & & & 0.039 \\
\hline$R 2_{S E}$ & class II Residual Trapping Efficiency & Fraction & & 0.027 & 0.054 & 0.075 & & & & & & 0.053 \\
\hline$R 3_{S E}$ & class III Residual Trapping Efficiency & Fraction & & 0.000 & 0.000 & 0.054 & & & & & & 0.009 \\
\hline$B_{S E}$ & Buoyant Storage Trapping Efficiency & Fraction & & 0.20 & 0.30 & 0.40 & & $\sigma$ & & & & 0.30 \\
\hline$P_{k}$ & Permeability Distribution & $\mathrm{mD}$ & 9 & 0.1 & 60 & 1,000 & 4.1 & 2.2 & 670 & 7,462 & Lognorm & 134 \\
\hline
\end{tabular}

\begin{tabular}{|c|c|c|c|c|c|c|c|c|}
\hline & ty Class Calculation & Units & Calculation & 1 & 1000 & Class I & Class II & Class III \\
\hline$\overline{R i}$ & Residual Trapping Injectivity Class Fraction & Fraction & (See Section 4) & 0.031 & 1.000 & 0.00 & 0.97 & 0.03 \\
\hline
\end{tabular}

\begin{tabular}{|c|c|c|c|c|}
\hline \multicolumn{2}{|c|}{ Volume Calculations } & \multirow{2}{*}{$\frac{\text { Units }}{\mathrm{ft}^{3}}$} & \multirow{2}{*}{$\begin{array}{l}\text { Calculation } \\
A_{S F} * T_{P l} * \Phi_{P l} * \mathrm{ft}^{2} / \text { acre }\end{array}$} & Distribution \\
\hline$\overline{S F_{P V}}$ & Storage Formation Pore Volume & & & $1.1 \mathrm{E}+12$ \\
\hline$B_{P V}$ & Buoyant Trapping Pore Volume & $\mathrm{ft}^{3}$ & $B_{P V}{ }^{*} \mathrm{Bbls} / \mathrm{MMbbls}{ }^{*} \mathrm{ft}^{3} / \mathrm{Bbls}$ & $7.6 \mathrm{E}+09$ \\
\hline$R_{G V}$ & Residual Trapping Gross Pore Volume & $\mathrm{ft}^{3}$ & $S F_{P V}-B_{P V}$ & $1.1 \mathrm{E}+12$ \\
\hline$B_{S V}$ & Buoyant Trapping Storage Volume & $\mathrm{ft}^{3}$ & $B_{P V}{ }^{*} B_{S E}$ & $2.3 \mathrm{E}+09$ \\
\hline$R_{P V}$ & Residual Trapping Pore Volume & $\mathrm{ft}^{3}$ & $R_{G V}{ }^{*} R_{W}$ & $3.2 \mathrm{E}+10$ \\
\hline
\end{tabular}

\section{OUTPUT CATEGORY RESULTS}

$K R R_{S R} \quad$ Known Recovery Replacement Storage Resource

$B_{S R} \quad$ Buoyant Trapping Storage Resource

$R 1_{S R} \quad$ Residual Trapping Class 1 Storage Resource

$R 2_{S R} \quad$ Residual Trapping Class 2 Storage Resource

$R 3_{S R} \quad$ Residual Trapping Class 3 Storage Resource

$T A_{S R} \quad$ Technically Accessable Storage Resource

Un

Calculation

Distribution

$K R_{\text {RES }}{ }^{*} B_{S E}{ }^{*} \rho_{\mathrm{CO}_{2}}{ }^{*} \mathrm{bbl} / \mathrm{MMbbl}{ }^{*} \mathrm{ft}^{3} / \mathrm{bbls}{ }^{*}\left(\mathrm{lbs} / \mathrm{ft}^{3}\right) /\left(\mathrm{kg} / \mathrm{m}^{3}\right) *$ tons $/ \mathrm{lbs}{ }^{*}$ megatons $/$ metric tons

$B_{S V}{ }^{*} \rho_{\mathrm{CO}_{2}}{ }^{*}\left(\mathrm{lbs} / \mathrm{ft}^{3}\right) /\left(\mathrm{kg} / \mathrm{m}^{3}\right)^{*}$ metric tons $/ \mathrm{lbs}{ }^{*}$ megatons/metric tons

$R_{P V}{ }^{*} R 1{ }^{*} R 1_{S E}{ }^{*} \rho_{C O_{2}}{ }^{*}\left(\mathrm{lbs} / \mathrm{ft}^{3}\right) /\left(\mathrm{kg} / \mathrm{m}^{3}\right) *$ metric tons $/ \mathrm{lbs}{ }^{*}$ megatons/metric tons

$R_{P V}{ }^{*} R 2{ }^{*} R 2_{\mathrm{SE}^{*}}{ }^{*} \rho_{\mathrm{CO}_{2}}{ }^{*}\left(\mathrm{lbs} / \mathrm{ft}^{3}\right) /\left(\mathrm{kg} / \mathrm{m}^{3}\right){ }^{*}$ metric tons $/ \mathrm{lbs}{ }^{*}$ megatons/metric tons

$R_{P V}{ }^{*} R 3{ }^{*} R 3_{S E}{ }^{*} \rho_{\mathrm{CO}_{2}}{ }^{*}\left(\mathrm{lbs} / \mathrm{ft}^{3}\right) /\left(\mathrm{kg} / \mathrm{m}^{3}\right){ }^{*}$ metric tons $/ \mathrm{lbs}{ }^{*}$ megatons/metric tons $B_{S R}+R 1_{S R}+R 2_{S R}+R 3_{S R}$ 
SAU Name

\begin{tabular}{|c|c|c|c|c|c|c|c|c|c|c|c|c|}
\hline Corr Matrix & $A_{S F}$ & $T_{P I}$ & $\phi_{P l}$ & $R_{w o}$ & $B_{P V}$ & $K R_{R E S}$ & $\rho_{\mathrm{CO}_{2}}$ & $R 1_{S E}$ & $R 2_{S E}$ & $R 3_{S E}$ & $B_{S E}$ & $P_{k}$ \\
\hline$A_{S F}$ & 1 & & & & & & & & & & & \\
\hline$T_{P l}$ & 0 & 1 & & & & & & & & & & \\
\hline$\Phi_{P l}$ & 0 & 0 & 1 & & & & & & & & & \\
\hline$R_{w}$ & 0 & 0 & 0 & 1 & & & & & & & & \\
\hline$B_{P V}$ & 0.38 & 0.53 & 0.53 & 0 & 1 & & & & & & & \\
\hline$K R_{\text {RES }}$ & 0 & 0 & 0 & 0 & 0.53 & 1 & & & & & & \\
\hline$\rho_{\mathrm{CO}_{2}}$ & 0 & 0 & 0 & 0 & 0 & 0 & 1 & & & & & \\
\hline$R 1_{S E}$ & 0 & 0 & 0 & 0 & 0 & 0 & 0 & 1 & & & & \\
\hline$R 2_{S E}$ & 0 & 0 & 0 & 0 & 0 & 0 & 0 & 0 & 1 & & & \\
\hline$R 3_{S E}$ & 0 & 0 & 0 & 0 & 0 & 0 & 0 & 0 & 0 & 1 & & \\
\hline$B_{S E}$ & 0 & 0 & 0 & 0 & 0 & 0 & 0 & 0 & 0 & 0 & 1 & \\
\hline$P_{k}$ & 0 & 0 & 0.23 & 0 & 0 & 0 & 0 & 0 & 0 & 0 & 0 & 1 \\
\hline
\end{tabular}

Constants \& Conversion Factors

\begin{tabular}{lcl}
\hline area & 43560 & $\mathrm{ft}^{2} / \mathrm{acre}$ \\
volume & 1000000 & $\mathrm{bbl} / \mathrm{MMbbl}$ \\
volume & 5.61 & $\mathrm{ft}^{3} / \mathrm{bbl}$ \\
density & 0.06234 & $\mathrm{Ibs} / \mathrm{ft}^{3} / \mathrm{kg} / \mathrm{m}^{3}$ \\
mass & 1000000 & metric tons / megaton \\
mass & 2204.62 & $\mathrm{lbs} /$ metric ton \\
Z(1/10) & 1.281 & one tailed \\
Z(1/15) & 1.5 & one tailed \\
Z(1/100) & 2.327 & one tailed \\
Z(1/1000) & 3.09 & one tailed \\
\hline
\end{tabular}

USGS $\mathrm{CO}_{2}$ MONTE CARLO RESULTS

Basin Name

SAU Name

SAU Code

\begin{tabular}{|l|r|r|r|r|}
\hline \multicolumn{7}{c|}{ SAU Code } \\
\cline { 2 - 6 }$(\mathrm{MT})$ & $\mathrm{P}_{95}$ & $\mathrm{P}_{50}$ & \multicolumn{1}{c|}{$\mathrm{P}_{5}$} & \multicolumn{1}{c|}{ Mean } \\
\hline$K R R_{S R}$ & 30 & 40 & 53 & 41 \\
\cline { 2 - 6 }$B_{S R}$ & 34 & 44 & 56 & 45 \\
\cline { 2 - 6 }$R 1_{S R}$ & 0.0 & 0.0 & 0.0 & 0.0 \\
\cline { 2 - 6 }$R 2_{S R}$ & 2 & 23 & 91 & 32 \\
\cline { 2 - 6 }$R 3_{S R}$ & $<0.1$ & 0.1 & 0.7 & 0.2 \\
\cline { 2 - 6 }$T A_{S R}$ & 43 & 68 & 140 & 77 \\
\hline
\end{tabular}




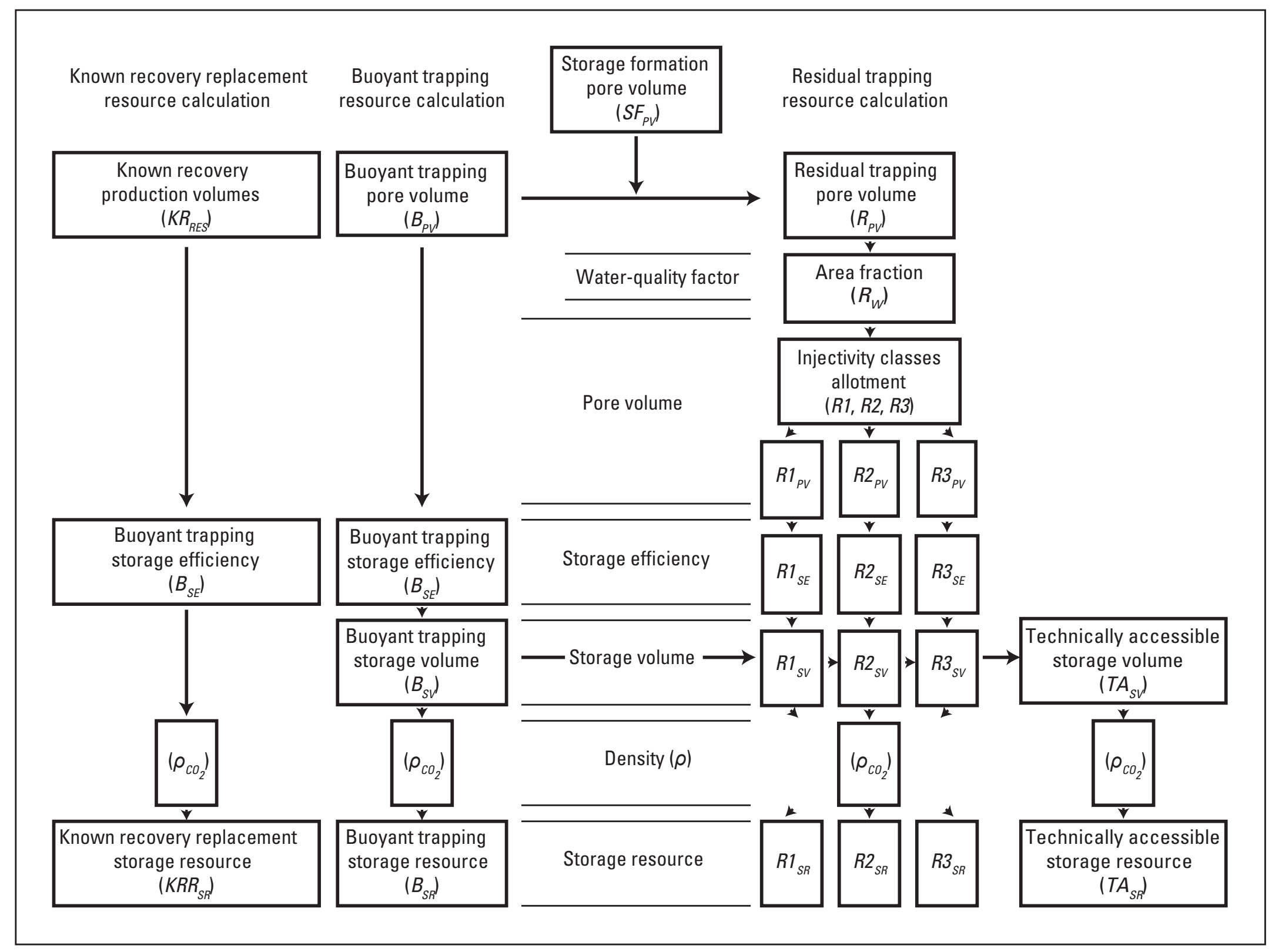

Figure 10. Flow diagram of the key steps for calculating known recovery replacement storage resources, buoyant trapping storage resources, residual trapping storage resources $\left(\mathrm{R} 1_{\mathrm{SR}^{\prime}} \mathrm{R} 2_{\mathrm{SR}^{\prime}}, \mathrm{R} 3_{\mathrm{SR}}\right)$, and technically accessible storage resources. Residual trapping injectivity categories are represented as class 1 (R1), class 2

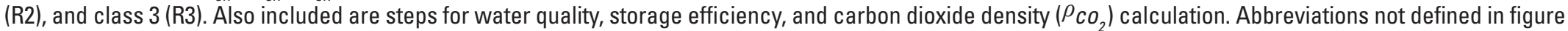
are defined in front part of report. 


\section{Aggregation}

The calculated $\mathrm{CO}_{2}$ mass for each $\mathrm{SAU}$ is in the form of a probabilistic distribution, reported as the $\mathrm{P}_{5}, \mathrm{P}_{50}, \mathrm{P}_{95}$, and mean, and recorded as 10,000 individual storage resource estimates. The $\mathrm{CO}_{2}$ assessment must then combine the SAU results to basin, regional, and national scales. The mean values may simply be added together, but the same approach is not valid for different probability intervals (percentiles), because of the effect of input correlations on the shape of the aggregate distribution. The aggregation procedure allows calculation of new probability percentiles (for example $\mathrm{P}_{5}$ and $\mathrm{P}_{95}$ ) for the combined distributions by using estimated correlation coefficients between each pair of SAUs. This procedure is discussed in detail in the forthcoming report on probabilistic aggregation of $\mathrm{CO}_{2}$ SAUs (Blondes and others, in press).

\section{Summary}

In implementing the USGS national geologic carbon dioxide storage resources assessment, some minor changes to the methodology (Brennan and others, 2010) were deemed necessary. In order to allow replication of the output values, it is important to document all details of the USGS calculations. This report discusses the details of

1. input parameter estimation (density, storage efficiency, injectivity classes, and buoyant trapping pore volume),

2. a new input parameter that addresses EPA waterquality regulations,

3. parameter estimation (formation volume factors) that factor into the input parameters, and

4. probabilistic model calculations (choice of distributions, Monte Carlo calculation methods, and aggregation methods).

The new water-quality factor and the distribution choices are the main changes from the Brennan and others (2010) methodology that have the largest effect on storage resource estimation. In some cases, the above sections are summaries of more detailed reports in preparation or review. All input and output data and summaries will be available with the assessment data, results, and summary reports scheduled to be published in 2013. (U.S. Geological Survey Geologic Carbon Dioxide Storage Resources Assessment Team, in press, a,b).

\section{Acknowledgments}

We greatly appreciate the reviews of Olga Popova, Mitchell Small, Angela Goodman, and Robert Milici. We also thank the participants of the USGS/NETL Storage Efficiency Workshop held in Austin Texas, July 17-18, 2012.

\section{References Cited}

Aitchison, John, 1986, The statistical analysis of compositional data (15th ed.): London, New York, Chapman and Hall, 416 p.

Attanasi, E.D., and Charpentier, R.R., 2007, A program for partitioning shifted truncated lognormal distributions into size-class bins: U.S. Geological Survey Open-File Report 2007-1260, 14 p., accessed October 15, 2012, at http:// pubs.usgs.gov/of/2007/1260/.

Bachu, Stefan, 2003, Screening and ranking of sedimentary basins for sequestration of $\mathrm{CO}_{2}$ in geological media in response to climate change: Environmental Geology, v. 44, p. 277-289.

Bennion, D.B., and Bachu, Stefan, 2005, Relative permeability characteristics for supercritical $\mathrm{CO}_{2}$ displacing water in a variety of potential sequestration zones in the Western Canada Sedimentary Basin, SPE 95547, in Society of Petroleum Engineers Annual Technical Conference and Exhibition, Dallas, Tex., 2005, Proceedings: Richardson, Tex., Society of Petroleum Engineers, 15 p.

Bennion, D.B., and Bachu, Stefan, 2008, Drainage and imbibition relative permeability relationships for supercritical $\mathrm{CO}_{2}$ /brine and $\mathrm{H}_{2} \mathrm{~S}$ /brine systems in intergranular sandstone, carbonate, shale, and anhydrite rocks: Society of Petroleum Engineers Reservoir Evaluation and Engineering, v. 11, no. 3, p. 487-496.

Benson, S.M., and Cook, Peter, 2005, Underground geological storage, chap. 5 of Metz, B., Davidson, O., de Coninck, H., Loos, M., and Meyer, L., eds., Intergovernmental Panel on Climate Change (IPCC), Working Group III, IPCC special report on carbon dioxide capture and storage: New York, Cambridge University Press, p. 195-276.

Blackwell, D.D., and Richards, M.C., 2004, Geothermal map of North America: American Association of Petroleum Geologists, scale 1:6,500,000.

Blackwell, D.D., Steele, J.L., and Carter, L.C., 1991, Heat flow patterns of the North American continent: A discussion of the DNAG geothermal map of North America, in Slemmons, D.B., Engdahl, E.R., Zoback, M.D., and Blackwell, D.D., eds., Neotectonics of North America: Boulder, Colo., Geological Society of America, Decade Map, v. 1, 32 p.

Blondes, M.S., Schuenemeyer, J., Olea, R.A. and Drew, L.J., in press, Aggregation of carbon dioxide sequestration storage assessment units: Stochastic Environmental Research and Risk Assessment (SERRA).

Breit, G.N., 2002, Produced waters database: U.S. Geological Survey online database, accessed October 15, 2012, at http://energy.cr.usgs.gov/prov/prodwat/. 
Brennan, S.T., Burruss, R.C., Merrill, M.D., Freeman, P.A., and Ruppert, L.F., 2010, A probabilistic assessment methodology for the evaluation of geologic carbon dioxide storage: U.S. Geological Survey Open-File Report 2010-1127, 31 p., accessed, October 15, 2012, at http://pubs.usgs.gov/ of $/ 2010 / 1127 /$.

Burruss, R.C., Brennan, S.T., Freeman, P.A., Merrill, M.D., Ruppert, L.F., Becker, M.F., Herkelrath, W.N., Kharaka, Y.K., Neuzil, C.E., Swanson, S.M., Cook, T.A., Klett, T.R., Nelson, P.H., and Schenk, C.J., 2009, Development of a probabilistic assessment methodology for evaluation of carbon dioxide storage: U.S. Geological Survey Open-File Report 2009-1035, 81 p., accessed, October 15, 2012, at http://pubs.usgs.gov/of/2009/1035/.

Burton, M., Kumar, N., and Bryant, S.L., 2008, Time-dependent injectivity during $\mathrm{CO}_{2}$ storage in aquifers, SPE 11397, in SPE/DOE Symposium on Improved Oil Recovery, Tulsa, Okla., 2008, Proceedings: Richardson, Tex., Society of Petroleum Engineers, 15 p.

Dilmore, R.M., Allen, D.E., Jones, J.R.M., Hedges, S.W., and Soong, Y., 2008, Sequestration of dissolved $\mathrm{CO}_{2}$ in the Oriskany Formation: Environmental Science Technology, v. 42, no. 8 , p. $2760-2766$.

Ennis-King, J., and Paterson, L., 2001, Reservoir engineering issues in the geological disposal of carbon dioxide, in Williams, D., Durie, B, McMullan, P., Paulson, C., and Smith A., eds.,International Conference on Greenhouse Gas Control Technologies, 5th, Cairns, Queensland, Australia, 2000, Proceedings: Cairns, Queensland, Australia, CSIRO, p. 290-295.

Gorecki, C.D., Sorensen, J.A., Bremer, J.M., Knudsen, D.J., Smith, S.A., Steadman, E.N., and Harju, J.A., 2009, Development of storage coefficients for determining the effective $\mathrm{CO}_{2}$ storage resource in deep saline formations, SPE 126444 , in Society of Petroleum Engineers International Conference on $\mathrm{CO}_{2}$ Capture, Storage, and Utilization, San Diego, Calif., 2009, Proceedings: Richardson, Tex., Society of Petroleum Engineers, 35 p.

Holloway, Sam, 2001, Storage of fossil fuel-derived carbon dioxide beneath the surface of the earth: Annual Review of Energy and the Environment, v. 26, p. 145-166.

IEA Greenhouse Gas R\&D Programme, 2009, Development of storage coefficients for $\mathrm{CO}_{2}$ storage in deep saline formations: IEA Greenhouse Gas R\&D Programme (IEA GHG), no. $2009 / 13,118$ p.

IHS Energy Group, 2010 [includes data current as of December 23, 2009], PIDM (Petroleum Information Data Model) relational U.S. well data: IHS Energy Group, database available from IHS Energy Group, 15 Inverness Way East, D205, Englewood, CO 80112, U.S.A.
Juanes, Ruben, MacMinn, C.W., and Szulczewski, M.L., 2010, The footprint of the $\mathrm{CO}_{2}$ plume during carbon dioxide storage in saline aquifers: Storage efficiency for capillary trapping at the basin scale: Transport in Porous Media, v. 82 , no. 1 , p. 19-30.

Keelan, D.K., and Pugh, V.J., 1975, Trapped-gas saturations in carbonate formations: SPE Journal, v. 15, no. 2, p. 149-160.

Klett, T.R., Schmoker, J.W., and Charpentier, R.R., 2005, U.S. Geological Survey input-data form and operational procedure for the assessment of conventional petroleum accumulations, chap. 20 of USGS Southwestern Wyoming Province Assessment Team, Petroleum systems and geologic assessment of oil and gas in the Southwestern Wyoming Province, Wyoming, Colorado, and Utah: U.S. Geological Surve Digital Data Series DDS-69-D, 7 p., accessed August 20, 2012, at http://certmapper.cr.usgs.gov/data/noga00/natl/ text/CH_20.pdf.

Kopp, A., Class, H., and Helmig, R., 2009a, Investigations on $\mathrm{CO}_{2}$ storage capacity in saline aquifers, Part 1, Dimensional analysis of flow processes and reservoir characteristics: International Journal of Greenhouse Gas Control, v. 3, no. 3, p. 263-276.

Kopp, A., Class, H., and Helmig, R., 2009b, Investigations on $\mathrm{CO}_{2}$ storage capacity in saline aquifers, Part 2, Estimation of storage capacity coefficients: International Journal of Greenhouse Gas Control, v. 3, no. 3, p. 277-287.

MacMinn, C.W., Szulczewski, M.L., and Juanes, Ruben, 2010, $\mathrm{CO}_{2}$ migration in saline aquifers, Part 1, Capillary trapping under slope and groundwater flow: Journal of Fluid Mechanics, v. 662, p. 329-351.

Mao, S., and Duan, Z., 2008, The P,V,T, x properties of binary aqueous chloride solutions up to $\mathrm{T}=573 \mathrm{~K}$ and 100 MPa: Journal of Chemical Thermodynamics, v. 40, no. 7, p. 1046-1063.

May, F., Knopf, S., Müller, C., and Hoth, P., 2009, $\mathrm{CO}_{2}$ storage options in Germany, in Grobe, M., Pashin, J.C., and Dodge, R.L., eds., Carbon dioxide sequestration in geological media - State of the science (1st ed.): AAPG Studies in Geology, v. 59, p. 35-45.

Meyer, M.A., and Booker, J.M., 2001, Eliciting and analyzing expert judgement, a practical guide: ASA-SIAM Series on Statistics and Applied Probability, Alexandria, Va. Society for Industrial and Applied Mathematics, $459 \mathrm{p}$.

Lemmon, E.W., McLinden, M.O., and Friend, D.G., 2009, Thermophysical properties of fluid systems, in Linstrom, P.J., and Mallard, W.G., eds., NIST chemistry WebBook: National Institute of Standards and Technology (NIST) Standard Reference Database Number 69, accessed December 10, 2012, at http://webbook.nist.gov/chemistry. 
Nehring Associates, Inc., 2010 [data current as of December 2008], The significant oil and gas fields of the United States: Colorado Springs, Colo., Nehring Associates, Inc., database available from Nehring Associates, Inc., P.O. Box 1655, Colorado Springs, CO 80901, U.S.A.

Okabe H., and Tsuchiya Y., 2008, Experimental investigation of residual $\mathrm{CO}_{2}$ saturation distribution in carbonate rocks, in International Symposium of the Society of the Core Analysts, Abu Dhabi, 2008, Proceedings: Abu Dhabi, Society of the Core Analysts, $6 \mathrm{p}$.

Okabe, H., Tsuchiya, Y., Pentland, C.H., Iglauer, S., and Blunt, M.J., 2010, Residual $\mathrm{CO}_{2}$ saturation distributions in rock samples measured by X-ray CT, in Alshibli, K.A., and Reed, A.H., eds., Advances in computed tomography for geomaterials: GeoX 2010, New Orleans, La., 2010, Proceedings: New Orleans, La., p. 381-389.

Okwen, R.T., Stewart, M.T., and Cunningham, J.A., 2010, Analytical solution for estimating storage efficiency of geologic sequestration of $\mathrm{CO}_{2}$ : International Journal of Greenhouse Gas Control, v. 4, p. 102-107.

Olea, R.A., 2011, On the use of the beta distribution in probabilistic resource assessments: Natural Resources Research, v. 20 , no. 4 , p. $377-388$.

Palisade Corporation, 2010, @Risk for Excel, version 5.7: Ithaca, N.Y., Palisade Corporation software.

Public Law 110-140, 2007, Energy Independence and Security Act of 2007: Washington, D.C., U.S. Government Printing Office, accessed August 20, 2012, at http://frwebgate. access.gpo.gov/cgi-bin/getdoc.cgi?dbname $=110 \_$cong public_laws\&docid=f:publ140.110.pdf.

Span, R., and Wagner, W., 1996, A new equation of state for carbon dioxide covering the fluid region from the triplepoint temperature to $1100 \mathrm{~K}$ at pressures up to $800 \mathrm{MPa}$ : Journal of Physical and Chemical Reference Data, v. 25, no. 6, p. 1509-1596.

Szulczewski, M.L., MacMinn, C.W., Herzog, H.J., and Juanes, R., 2012, Lifetime of carbon capture and storage as a climate-change mitigation technology: Proceedings of the National Academy of Sciences of the U.S.A., v. 109, no. 14, p. 5185-5189.

U.S. Department of Energy, National Energy Technology Laboratory, 2010, Rocky Mountain basins produced water database: Department of Energy National Energy Technology Laboratory online database, accessed October 15, 2012, at http://www.netl.doe.gov/technologies/oil-gas/software/ database.html.
U.S. Department of Energy, National Energy Technology Laboratory, 2012, The North American Carbon Storage Atlas (1st ed.): U.S. Department of Energy, National Energy Technology Laboratory, 52 p., accessed October 15, 2012, at http://www.netl.doe.gov/technologies/carbon_seq/ refshelf/NACSA2012.pdf.

U.S. Environmental Protection Agency, 2009, Safe Drinking Water Act (SDWA): Washington, D.C., U.S. Environmental Protection Agency Web site, accessed October 15, 2012, at http://www.epa.gov/ogwdw/sdwa/index.html.

U.S. Environmental Protection Agency, 2010, Federal requirements under the Underground Injection Control (UIC) for carbon dioxide $\left(\mathrm{CO}_{2}\right)$ geologic sequestration (GS) wells: Washington, D.C., U.S. Environmental Protection Agency Web site, accessed October 15, 2012, at http://water.epa. gov/type/groundwater/uic/class6/gsregulations.cfm.

U.S. Geological Survey Geologic Carbon Dioxide Storage Resources Assessment Team, in press, a, National assessment of geologic carbon dioxide storage resources - results: U.S. Geological Survey Circular 1386.

U.S. Geological Survey Geologic Carbon Dioxide Storage Resources Assessment Team, in press, b, National assessment of geologic carbon dioxide storage resources - summary: U.S. Geological Survey Fact Sheet 2013-3020.

van der Meer, L.G.H., 1995, The $\mathrm{CO}_{2}$ storage efficiency of aquifers: Energy Conversion Management, v. 36, no. 6-9, p. $513-518$.

Verma, M.K., 2012, Calculation of hydrocarbon-in-place in gas and gas-condensate reservoirs - Carbon dioxide sequestration: U.S. Geological Survey Open-File Report 20121033, 14 p., accessed October 15, 2012, at http://pubs.usgs. gov/of/2012/1033/.

Vose, D., 1996, Quantitative risk analysis, A guide to Monte Carlo simulation modeling (1st ed.): New York, Wiley, $340 \mathrm{p}$.

Wagner, W., and Pruss, A., 2002, The IAPWS formulation 1995 for the thermodynamic properties of ordinary water substance for general and scientific use: Journal of Physical and Chemical Reference Data, v. 31, no. 2, p. 387-535.

Warwick, P.D., and Corum, M.D., eds., 2012, Geologic framework for the national assessment of carbon dioxide storage resources: U.S. Geological Survey Open-File Report 2012-1024, chaps. A-C, available only at http://pubs.usgs. gov/of/2012/1024/. 


\section{Appendix 1. Reservoir Growth Functions}

\section{By Emil Attanasi}

Many of the inputs for $\mathrm{CO}_{2}$ storage resource rely on estimates of oil and gas resources in the subsurface. In particular, known recovery or reservoir size, defined as the sum of cumulative production to date and proved reserves, is used to estimate buoyant pore volume (see Section 6.1). However, estimates of known recovery tend to increase as reservoir development occurs and new recovery techniques are applied (Arrington, 1960; Attanasi and Root, 1994). Reservoir growth modeling allows the prediction of ultimate reservoir sizes with cumulative growth functions. Cumulative growth functions predict the reservoir's size as a multiple of the initial estimate. These functions are used to project known recovery volumes to the year 2050 .

\section{A1.1. Data}

The "Significant Oil and Gas Fields of the United States Database" by Nehring Associates, Inc. (2010), used in this study, included reservoir size estimates for accumulations discovered from 1901 through 2008 (Nehring Associates, Inc., 2010). For each accumulation there is an estimate of known recovery from 1982 through 2008. Here, only conventional accumulations are used for calibrating the cumulative growth functions. Conventional accumulations are discrete deposits having a well-defined down-dip oil and gas water contact from which oil, gas, or natural gas liquids (NGL) can be extracted by standard methods. Reservoirs are classified as either oil or gas on the basis of the gas to oil ratio (GOR): gas reservoirs have ratios of at least 20,000 cubic $\mathrm{ft}$ of gas to barrel of oil based on the 2008 estimate of known recovery. Reservoirs discovered before 1901 and those without discovery dates are excluded. Statisticians also partition the sample data to remove parts of the data series where data are known to introduce bias. For calibration of oil reservoir cumulative growth functions, California heavy oil reservoirs and Williston Basin oil reservoirs (predominantly oils from shale) together representing about 11 percent of the oil discovered, were excluded. For calibration of gas reservoir cumulative growth functions, to mitigate the effect of gas price regulation on reservoir size estimates, growth functions were based on the series of estimates starting from 1993 through 2008. In addition, discrete low permeability gas reservoirs (considered conventional by the USGS) were removed for the same reason the heavy oil was removed from the oil reservoir data. The gas reservoirs of southwest Wyoming were removed because gas was actually stranded until the Rocky Express Pipeline was built. Reservoirs that were excluded only amounted to 7 percent of the gas of the 2008 known recovery estimate.
Table A1-1 shows part of a discovery table from 1982 through 1985. Each row is a vintage representing the sum of the known recoveries of all reservoirs discovered in a specific year. Entries from left to right represent the sum of known recoveries of that vintage as of a specific estimation date: 1982,1983 , through 2008 . The discovery table is the basic data used for calibration of the cumulative growth function.

Table A1-1. Part of a discovery table. Estimated known recovery in discovered oil reservoirs by discovery year or vintage (vertical) with estimation year (horizontal). The entries from left to right are successive estimates of total volume of oil in oil reservoirs. Known recovery data are from Nehring Associates, Inc. (2010).

\begin{tabular}{ccccc}
\hline \multirow{2}{*}{$\begin{array}{c}\text { Reservoir } \\
\text { discovery } \\
\text { year }\end{array}$} & \multicolumn{4}{c}{ Year of estimate } \\
\cline { 2 - 5 } & $\mathbf{1 9 8 2}$ & $\mathbf{1 9 8 3}$ & $\mathbf{1 9 8 4}$ & $\mathbf{1 9 8 5}$ \\
\hline 1979 & 120 & 133 & 157 & 170 \\
1980 & 92 & 109 & 125 & 130 \\
1981 & 97 & 143 & 153 & 156 \\
1982 & 34 & 108 & 142 & 160 \\
1983 & 0 & 40 & 93 & 104 \\
1984 & 0 & 0 & 35 & 88 \\
1985 & 0 & 0 & 0 & 37 \\
\hline
\end{tabular}

\section{A1.2. Calibration of cumulative growth functions}

Observing table A1-1, for any vintage, the annual growth factor for reservoirs of age $i$ is the ratio of the estimated total known recoveries at $(i+1)$ years after discovery to the estimated total known recoveries i years after discovery. Similarly for a particular vintage, the cumulative growth factor is the ratio of the total estimated reservoir sizes $m$ years after discovery to the total of the initial estimated reservoir sizes (year 0). Cumulative growth factors can also be computed as the successive products of annual growth factors.

For each vintage, the cumulative growth function is represented by the series of cumulative growth factors computed for each successive year after discovery. Changes in estimated known recovery conform to the relation

$$
\hat{c}(i, j+m)=c(i, j)[G(j+m-i) / G(j-i)]+d(i, j, m),
$$


where $c(i, j)$ is the aggregate known recovery in year $\mathrm{j}$ of vintage $i$ reservoirs (that is, reservoirs discovered in year $\mathrm{i}$ ), $\mathrm{m}$ is elapsed time (in years where $m>0), \hat{c}(i, j+m)$ is the estimate of aggregate known recovery in year $\mathrm{j}+\mathrm{m}$ of vintage i reservoirs, $\mathrm{d}(\mathrm{i}, \mathrm{j}, \mathrm{m})$ is the deviation or error term and $\mathrm{G}(\mathrm{)})$ is the cumulative growth factor. Equation A1 implies that, for a specified vintage with discovery year $\mathrm{i}$, the aggregate of the known field recoveries in year $\mathrm{j}+\mathrm{m}$ can be determined by multiplying the aggregate of the estimated reservoir recoveries in year $\mathrm{j}$ by an appropriate factor that is the ratio of cumulative growth factors for reservoir ages $(j+m-i)$ and $(j-i)$. $G(N)$ is bounded where $\mathrm{N}$ is the number of years after which the vintage is no longer allowed to grow. In particular, $G(0)=1$, and $G(n)$ is a constant when $\mathrm{n}>\mathrm{N}$, after $\mathrm{N}$ years where $\mathrm{N}$ may be the same as the time span over which the factors were computed (1901-2008).

The cumulative growth factors, $G(j+m-i)$, are computed using an optimization algorithm, called an Lp norm minimization (Nyquist, 1983), that minimizes the sum of absolute deviations that have been raised to the power $p$ where $p>0$,

$$
\operatorname{ssd}=\sum|\mathrm{d}(\mathrm{i}, \mathrm{j}, \mathrm{m})|^{\mathrm{p}}
$$

between all combinations of the actual and estimated aggregate field recoveries, $\hat{c}(i, j+m)$, within the data (that is, the discovery table) used in the analysis, where

$$
d(i, j, m)=c(i, j+m, m)-\hat{c}(i, j+m, m) .
$$

The sources of error which contribute to $d(i, j, m)$ arise from incomplete knowledge about geologic properties of the reservoir, errors in data, changes in recovery technology, and economic and market conditions. The distribution of $\mathrm{d}(\mathrm{i}, \mathrm{j}, \mathrm{m})$ is unknown and presumed non-normal.

The choice of $p$ enables the adaptation of the calibration method to the error function. If the errors (residuals) followed a normal distribution, $p=2$, the minimization of the sum of squared errors is optimal (Nyquist, 1983). In the case where the data include outliers, it is generally optimal to minimize the absolute value of the sum of the deviations, where $p=1$ (Nyquist, 1983). The choice of $p$ allows an extra degree of freedom for fitting the cumulative growth function to the data. For this study, the choice of $p$ was determined by examining model in-sample and out-of-sample prediction performance of the calibrated models using alternative values of $p$. To summarize, the above procedure provides, by the selection of the value of $p$, a means to mitigate outlier influence. The search over various values of $p$ for oil reservoirs showed that $p=1.5$ provided the smallest sample forecast error for 2001-2008. The search over various values of $p$ for gas reservoirs showed optimal sample predictive performance when $\mathrm{p}=2$.

The reservoir cumulative growth function coefficients for oil and gas reservoirs are shown in table A1-2. The age of the reservoir is defined as the number of years elapsed since the discovery year (first column in table A1-2). To project reservoir size in year 2050, multiply the 2008 estimated reservoir size by the ratio of the cumulative growth coefficient corresponding to the reservoir's age at year 2050 to cumulative growth coefficient corresponding to the reservoir's age at year 2008. ${ }^{1}$ For example, if an oil reservoir was discovered in 2002, then multiply the known recovery in 2008 by the ratio of the cumulative growth coefficient for oil reservoirs of age 48 to the cumulative growth coefficient for oil reservoirs of age six years. These grown volumes are then used in the Section 6 calculations.

Table A1-2. Growth function coefficients for oil and gas reservoirs. The Lp norm calibration exponents for oil and gas

\begin{tabular}{|c|c|c|}
\hline $\begin{array}{l}\text { Years since } \\
\text { discovery }\end{array}$ & $\begin{array}{l}\text { Oil reservoir } \\
\text { multiplier }\end{array}$ & $\begin{array}{c}\text { Gas reservoi } \\
\text { multiplier }\end{array}$ \\
\hline 0 & 1.00000 & 1.00000 \\
\hline 1 & 2.70499 & 2.84112 \\
\hline 2 & 3.69281 & 3.35768 \\
\hline 3 & 4.22540 & 3.49949 \\
\hline 4 & 4.47146 & 3.64729 \\
\hline 5 & 4.59156 & 3.80133 \\
\hline 6 & 4.71488 & 3.96188 \\
\hline 7 & 4.84151 & 4.12921 \\
\hline 8 & 4.97154 & 4.30361 \\
\hline 9 & 5.10507 & 4.48537 \\
\hline 10 & 5.24218 & 4.67481 \\
\hline 11 & 5.38298 & 4.87224 \\
\hline 12 & 5.52756 & 5.07802 \\
\hline 13 & 5.65003 & 5.29249 \\
\hline 14 & 5.77521 & 5.51602 \\
\hline 15 & 5.83131 & 5.74899 \\
\hline 16 & 5.88785 & 5.94284 \\
\hline 17 & 5.94493 & 6.14324 \\
\hline 18 & 6.00257 & 6.35039 \\
\hline 19 & 6.06076 & 6.56452 \\
\hline 20 & 6.11952 & 6.78588 \\
\hline 21 & 6.17885 & 7.01470 \\
\hline 22 & 6.23876 & 7.25124 \\
\hline 23 & 6.29924 & 7.49575 \\
\hline 24 & 6.36032 & 7.74851 \\
\hline 25 & 6.42198 & 8.00979 \\
\hline 26 & 6.48424 & 8.27988 \\
\hline 27 & 6.54711 & 8.55908 \\
\hline 28 & 6.61058 & 8.84769 \\
\hline 29 & 6.67467 & 9.14603 \\
\hline
\end{tabular}
reservoirs are $p=1.5$ and $p=2.0$, respectively.

${ }^{1}$ For cases when age is greater than 107 , use the 107 -year cumulative growth coefficient. 
Table A1-2. Growth function coefficients for oil and gas reservoirs. The $L p$ norm calibration exponents for oil and gas reservoirs are $p=1.5$ and $p=2.0$, respectively.-Continued
Table A1-2. Growth function coefficients for oil and gas reservoirs. The Lp norm calibration exponents for oil and gas reservoirs are $p=1.5$ and $p=2.0$, respectively.-Continued

\begin{tabular}{|c|c|c|c|c|c|}
\hline $\begin{array}{l}\text { Years since } \\
\text { discovery }\end{array}$ & $\begin{array}{l}\text { Oil reservoir } \\
\text { multiplier }\end{array}$ & $\begin{array}{l}\text { Gas reservoir } \\
\text { multiplier }\end{array}$ & $\begin{array}{c}\text { Years since } \\
\text { discovery }\end{array}$ & $\begin{array}{l}\text { Oil reservoir } \\
\text { multiplier }\end{array}$ & $\begin{array}{c}\text { Gas reservoir } \\
\text { multiplier }\end{array}$ \\
\hline 30 & 6.73939 & 9.45444 & 72 & 8.43247 & 13.82238 \\
\hline 32 & 6.87070 & 9.79235 & 74 & 8.47341 & 13.91774 \\
\hline 33 & 6.93731 & 9.96581 & 75 & 8.49396 & 13.96566 \\
\hline 35 & 7.07248 & 10.32200 & 77 & 8.53520 & 14.06201 \\
\hline 36 & 7.11626 & 10.50484 & 78 & 8.55590 & 14.07959 \\
\hline 37 & 7.15668 & 10.69092 & 79 & 8.57665 & 14.07959 \\
\hline 38 & 7.19734 & 10.88029 & 80 & 8.59744 & 14.07959 \\
\hline 39 & 7.23822 & 11.07302 & 81 & 8.61829 & 14.07959 \\
\hline 42 & 7.36226 & 11.62530 & 84 & 8.68114 & 14.07959 \\
\hline 43 & 7.40408 & 11.78395 & 85 & 8.70219 & 14.07959 \\
\hline 44 & 7.44614 & 11.94476 & 86 & 8.72329 & 14.07959 \\
\hline 45 & 7.48843 & 12.10777 & 87 & 8.74444 & 14.07959 \\
\hline 46 & 7.53097 & 12.27301 & 88 & 8.76564 & 14.07959 \\
\hline 47 & 7.57374 & 12.40774 & 89 & 8.78690 & 14.07959 \\
\hline 48 & 7.61676 & 12.47675 & 90 & 8.80820 & 14.07959 \\
\hline 49 & 7.66003 & 12.54615 & 91 & 8.82956 & 14.07959 \\
\hline 50 & 7.70354 & 12.61594 & 92 & 8.85097 & 14.07959 \\
\hline 57 & 8.01511 & 13.10262 & 99 & 9.00230 & 14.07959 \\
\hline 58 & 8.06063 & 13.17293 & 100 & 9.02413 & 14.07959 \\
\hline 59 & 8.10642 & 13.21829 & 101 & 9.03930 & 14.07959 \\
\hline 60 & 8.15167 & 13.26381 & 102 & 9.05450 & 14.07959 \\
\hline 61 & 8.17814 & 13.30948 & 103 & 9.06972 & 14.07959 \\
\hline 62 & 8.20470 & 13.35531 & 104 & 9.08497 & 14.07959 \\
\hline 63 & 8.23134 & 13.40130 & 105 & 9.10024 & 14.07959 \\
\hline 64 & 8.25807 & 13.44744 & 106 & 9.11554 & 14.07959 \\
\hline 65 & 8.28441 & 13.49375 & 107 & 9.13086 & 14.07959 \\
\hline 66 & 8.31082 & 13.54021 & & & \\
\hline 67 & 8.33097 & 13.58684 & & & \\
\hline 68 & 8.35118 & 13.63362 & & & \\
\hline 69 & 8.37143 & 13.68057 & & & \\
\hline 70 & 8.39172 & 13.72768 & & & \\
\hline 71 & 8.41207 & 13.77495 & & & \\
\hline
\end{tabular}




\section{Acknowledgments}

The authors thank Timothy Klett of the USGS Central Energy Resources Science Center and Troy Cook, formerly with the USGS Central Energy Resources Science Center, who assigned conventional, continuous reservoir designations, and province codes to the Nehring reservoir database.

\section{References Cited}

Arrington, J.R., 1960, Predicting the size of crude reserves is key to evaluating exploration programs: Oil and Gas Journal, v. 58, no. 9, 130-134.

Attanasi, E.D., and Root, D.H., 1994, The enigma of oil and gas field growth: American Association of Petroleum Geologists Bulletin, v. 78, no. 3, p. 321-332.

Nehring Associates, Inc., 2010 [data current as of December 2008], The significant oil and gas fields of the United States: Colorado Springs, Colo., Nehring Associates, Inc., database available from Nehring Associates, Inc., P.O. Box 1655, Colorado Springs, CO 80901, U.S.A.

Nyquist, H., 1983, The optimal Lp norm estimation in linear regression models: Communications in Statistical Theory and Methods, v. 12, p. 2511-2524. 


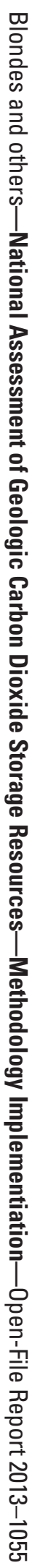

